\title{
Post-War Rebuilding: A New Battle for the Castle
}

\author{
To him must go the honour of pioneer discoveries on the site, as of course did the thrill of \\ first discovery which was largely denied to me. To him, alas, as to all turners of first furrows \\ must also go some criticism (Butcher 1961, 7)
}

A new opportunity to record the remains of Sheffield Castle emerged at the end of the 1950s in the wake of post-War rebuilding. The Brightside and Carbrook Co-op's store at the corner of Waingate and Exchange Street was destroyed during the bombing of Sheffield on the night of $12^{\text {th }} / 13^{\text {th }}$ December 1940 (Figure 4.1). In 1949, following the compulsory purchase of their bombed headquarters by the City Council, the Co-op moved their city-centre store to temporary prefabricated premises on nearby Angel Street, before receiving planning permission for a new, more imposing, headquarters in 1958 (Figure 4.2). ${ }^{17}$ While the Castle Hill Market buildings to the north of the Co-op store 'largely escaped damage' (Himsworth 1927-42, 20), and temporary structures (socalled Bailey bridges) were used to ensure continued access to them (Zasada 1996, 32), parts of the Castlegate area remained derelict into the late 1950s (Butcher 1972c, 5). In 1958 the Sheffield Corporation began construction of Castle Market on the site of the former Co-op, with the intention of incorporating the Castle Hill Market into a single market-complex (Butcher 1972a, 5; Richardson and Dennison 2014a, 36; see their fig. 3 for the main elements of this complex). The new Castle Market building was intended to rehouse traders from the 100-year-old Norfolk Market Hall to the south of Exchange Street, and Castle Hill Market was refurbished and provided with new access from Castlegate (see Figure 1.15). New buildings were constructed or rebuilt fronting onto Waingate from the junction of Exchange Street to the Bull \& Mouth public house at the corner of Castlegate (Zasada 1996, 32; Butcher 1972a, 10). As in the late 1920s, a formal programme of archaeological investigation was not required in advance of this regeneration of the area, but the castle remains encountered in the course of construction works were recorded by Leslie Butcher from Sheffield City Council's Architect's Department and John E. Bartlett, Deputy Director of the City Museum. In this chapter we discuss the nature of the recording undertaken and the resulting archive, which is an essential prelude to analysing what was found in the next chapter.

${ }_{17}$ This new home, Castle House, is now a Grade II listed building (ref. 1393220); English Heritage 2009; Anon. 1950 (see Epilogue).

\footnotetext{
How to cite this book chapter:

Moreland, J. and Hadley, D. (with A. Tuck and M. Rajic). 2020. Sheffield Castle: archaeology, archives, regeneration, 1927-2018, pp. 105-133. York: White Rose University Press. DOI: https://doi.org/10.22599/SheffieldCastle.d. CC BY-NC 4.0, https://creativecommons.org/licenses/by-nc/4.0
} 



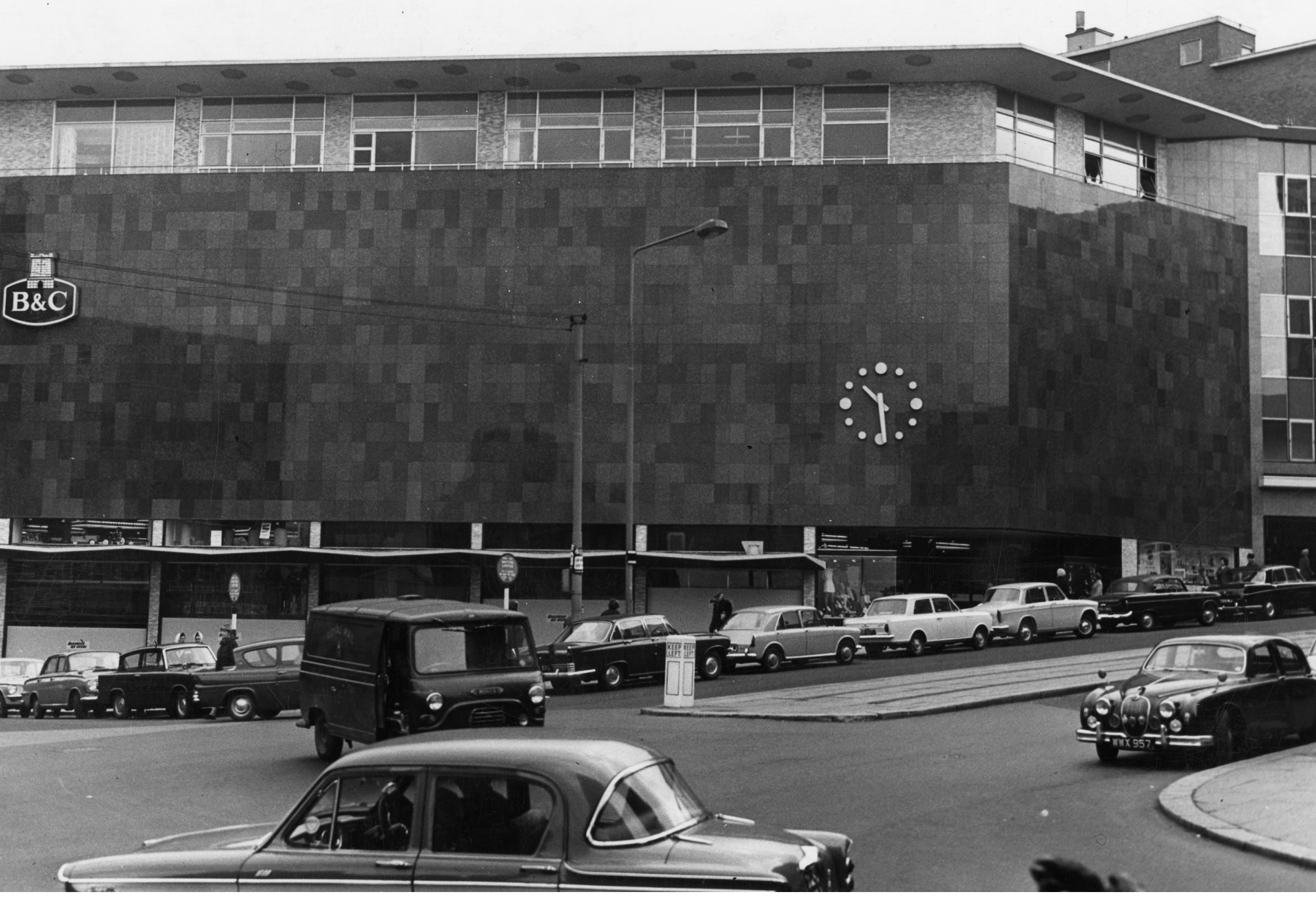

Figure 4.2: Castle House. The new home of the Brightside and Carbrook Co-op opened in 1964. With thanks to www.picturesheffield.com (s30254).

At first glance, our efforts here might appear forlorn. Over 20 years ago, Julien Parsons (1997, 1), then Keeper of Archaeology and Ethnography at Sheffield City Museum, bemoaned that 'some of Sheffield's most important archaeology has been destroyed with inadequate recording', while a review of previous investigations of Sheffield Castle dismissed the work undertaken by Butcher as having been conducted under 'restricted circumstances, taking the form of watching briefs with little opportunity for detailed recording' (Belford 1998, 6; for similarly pessimistic views see Davies and Willmott 2002, 6-9, 26; McCoy and Stenton 2009, 26). However, as with Armstrong and Himsworth in the late 1920s, while the circumstances under which Butcher and Bartlett operated were certainly restricted, their recording was nevertheless very detailed, and the character of the archaeological intervention was neither inadequate nor unusual for its time, and has been unjustly neglected in subsequent work. Although the two men shared responsibility for observing, recovering and recording the archaeology encountered during construction work, our greatest debt remains to Leslie Butcher (Figure 4.3) - his diligence and perseverance in recording the castle remains and trying to make sense of what he saw in the context of the earlier work of Armstrong and Himsworth is crucial to our knowledge and understanding of Sheffield Castle. This chapter accordingly begins with an outline of his archaeological career, which helps to explain why Butcher was charged with the Sheffield Castle 'watching brief'. We will also discuss his efforts to publish what he found, on which he had made considerable progress before his sudden death after a short illness in 1975. What emerges from this chapter is recognition of the quality of the work he, and Bartlett, 


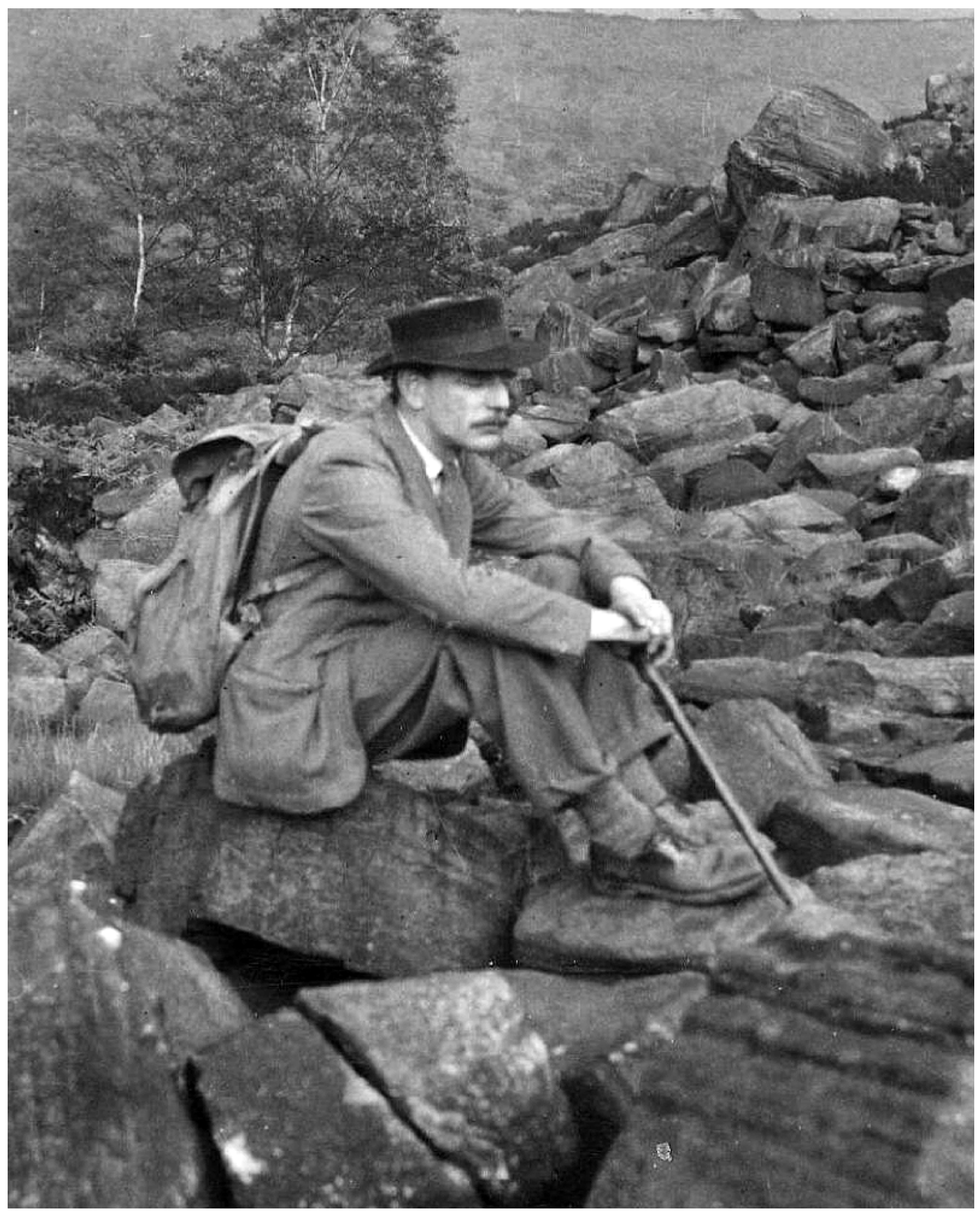

Figure 4.3: Leslie Butcher. A photograph taken at the Wharncliffe quern production site, Sheffield in the 1950s. Courtesy of Museums Sheffield.

carried out, and the immense value of local archaeological societies and museums in fostering widespread public enthusiasm in recording and championing the past in the mid-20th century, without which our knowledge of this major medieval and post-medieval site would have been immeasurably reduced. Leslie Butcher may have been unusual in the range of skills he possessed, in his determination, and in the opportunity he was 
granted to record Sheffield Castle, but the circumstances that led to the production of a valuable archaeological archive owe more to structural opportunities than to mere serendipity.

\section{Leslie Butcher: stalwart of local archaeology}

The various previous accounts of the excavations of Sheffield Castle outlined in Chapter 1 accord Leslie Butcher very little attention, but while he was not a full-time archaeologist - and, according to his son Nick (pers. comm.), was 'always very conscious of not being a formally trained archaeologist' - he was far from inexperienced. He was a highly skilled practitioner of archaeological field survey and illustration, was a key figure in the local archaeological scene, and operated in a context framed by national concerns about the archaeological heritage of the post-War decades. He trained as a mining surveyor, had a background in geology and was a long-time member of the Hunter Archaeological Society, spending much of his leisure time recording archaeological features in the countryside around Sheffield. His training led him to a particular interest in geological formations and soil development (Beswick and Merrills 1983, 17), and he was regarded among the local archaeological fraternity as having a very keen eye for landscape, with considerable abilities for distinguishing natural from man-made features (Bartlett 1977; Hart 1981, 53, 57, 63; Clayton 2012, 38). His differentiation of Bronze Age from Roman landscape features has been described as 'radical' for the time, and proven correct by subsequent fieldwork (Beswick and Merrills 1983, 16; Hart 1981, 53; Pearson and Oswald 2000). He also developed an interest in the relationship between distributions of prehistoric artefacts and varying soil types, but had not completed this work when he died.

Beyond short notes, very little of his work was published (Beswick and Merrills 1983, 17), apparently because, as his obituary by John Bartlett (1977) in the Transactions of the Hunter Archaeological Society puts it, 'he had a passion for perfection which prevented him all too often from achieving publication'. One exception was his excavation, conducted with Fredric (Freddie) Preston, a bank employee and lifelong member of the Hunter Archaeological Society (Jones 2012; Beswick 1997), of a section of the 'Roman Rig', or Ridge, an earthwork north-east of Sheffield, which had been identified as either an Iron Age defensive earthwork or a Roman road, although they principally encountered evidence of 19th-century tipping and quarrying (Preston and Butcher 1956). The other exception was a paper published in 1957 on quern working at Wharncliffe in north-west Sheffield (Butcher 1957). But, despite having published little, Butcher had a significant impact on the compilation and understanding of the archaeological record of the region. Particularly important was his collaboration with Preston, who was the local correspondent for the Ordnance Survey from 1949 to 1967, a voluntary position in which he provided the OS with details of the archaeology of the region so that they could include them on their maps (Beswick, pers. comm.; also Phillips 1980, 46-55). Together Butcher and Preston developed what became known as the 'Scheme for Archaeological Research' in the region around Sheffield, comprising a detailed inventory of archaeological monuments and finds, producing site records and distribution maps (Beswick 1997, 102-5). In this respect, Preston and Butcher ensured that the Hunter Archaeological Society was one of the first to respond to the initiative of the Council for British Archaeology, founded in 1944, which encouraged local archaeological societies to collect data that might otherwise be lost during post-War reconstruction (Beswick 1997, 102). The Scheme resulted in an index of sites, which was maintained by the Hunter Archaeological Society. It was hoped that local archaeology enthusiasts would consult the index and then be inspired to conduct their own fieldwork; this record eventually formed the basis for the South Yorkshire Sites and Monuments Record (Preston 1955; Bartlett 1977; Beswick 1995, 77; 1997, 103; Jones 2012, 35; Cockrell 2016, 59). As Pauline Beswick $(1997,105)$ has observed, the recording methods proposed in Butcher and Preston's Scheme 'predated the issue of the CBA's official record card [and] are so far-sighted as to foreshadow the County Sites \& Monuments Records, begun officially only in the 1970s' (Figure 4.4).

Butcher was responsible for mapping the archaeological remains recorded through the Scheme and his skills as a draughtsman were already recognised in the mid-1950s, when he was asked to provide maps and plans for the volume published following the hosting of the British Association for the Advancement of Science in Sheffield in 1956 (Linton 1956), comprising chapters on the natural history, prehistory and history of the region. Butcher illustrated the chapter on 'Prehistory' in which the section on the 'Palaeolithic, Neolithic and Bronze Ages' was written by Leslie Armstrong, while that on the 'Iron Age and Roman Period' was by Bartlett 
and Preston. Butcher was, thus, well connected with both local and national figures in archaeology before he took on the recording of Sheffield Castle, a fact that has been overlooked by previous reviews of the history of excavation of the site.

After Butcher's death, members of the Hunter Archaeological Society undertook 'The Butcher Project' to bring his work to publication. This involved examining in the field all of the sites that Butcher had recorded,

The Hunter Axahaeological Society, Researah Sub-Committee.

\section{SCHEME FOR ARCHAEOLOGICAL RESEARCH,}

I. Objects. The objects of the Scheme are:-

(1) to encourage and co-ordinate individual and collective archaeological research within the Society;

(2) to index and to record on period maps the archaeological sites and finds within the agreed area;

(3) to correlate the archaeological evidence with the natural features of the area; and

(4) to seek further archaeological evidence.

II. Area. The Scheme shall cover the area approximately contained by a line joining Woodhead, Edale, Baslow, Eckington, the YorkshireDerbyshire boundary as far as the Nottinghamshire boundary, Naltby, Adwick-upon-Deame and Woodhead.

III. Period. The Scheme shall cover all periods up to and including the Medieval.

IV. Evidence. The evidence to be indexed and recorded shall comprise:-

(1) published sites and finds;

(2) sites and finds resulting from the Scheme; and

(3) unpublished sites and finds with the consent of those having knowledge of then.

v. Maps. The maps shall be tranoparencies based on the 1-in. 0.S. maps, and shall include:-

(1) maps showing the natural features; and

(2) archaeological distribution maps.

VI. Method of Research. Each specific line of Research shall be undertaken by an individual or by a small group, in order to preserve the personal association of the individual(s). with the work.

The individual or the group leader shall be responsible for seeing that all necessary permissions have been obtained.

VII. Results of Research. The Index and Maps shall be the property of the Society and shall be kept by the Sub-Committee.

The Index and Maps may be consulted by nembers of the Society, by members of other archaeological bodies and (at the Sub-Committee's discretion) by other persons.

Provided that the use in any form of publication of information obtained from the Index and Maps shall require the prior approval of the Society (to be given in such manner as the Committee shall direct).

The results of each specific line of rcscarch may be published separately and pending publication may be kept by the Sub-Committee in the same way and under the same conditions as the Index and Maps.

(Adopted by the Hesearch Sub-Committce, 1949; revised by the Kesearch Sub-Committee, 1967)

Figure 4.4: The Scheme for Archaeological Research in the region around Sheffield. Devised by Freddie Preston and Leslie Butcher in 1949; it was revised in 1967. Hunter Archaeological Society. 
collating and, where necessary, updating his notes and using these to draw up plans for publication (Beswick and Merrills 1983, 17). However, only two papers ensued. His former collaborator Graham Makepeace (1985) wrote up the Romano-British settlement Butcher had surveyed and excavated at Whitley, Wharncliffe, while Pauline Beswick and Dariel Merrills (1983) published a summary of his various surveys of mainly prehistoric and Romano-British settlements and field systems in North Derbyshire and South Yorkshire, accompanied by examples of his many plans and maps. This paper described him as 'a pioneer landscape archaeologist whose achievements deserve to be more widely known' (Beswick and Merrills 1983, 16). He had been planning a book on his surveys at the time of his death, and his archive reveals his systematic approach to recording earthworks. Butcher was clearly influenced by a Council for British Archaeology method statement from 1948 concerning the recording of Bronze Age features, which stated that

field systems and enclosed areas should be not merely photographed or roughly mapped, but precisely surveyed and measured. Only by this means will it be possible to evaluate the size and subsistence economics of the inhabitants, and so obtain a realistic picture of the mode of life and social organization; in other words, to make prehistory live (Hawkes and Piggott 1948, 91; Beswick and Merrills 1983, 16; Heath 2003, 30).

His early work, using compass and pace to measure features, was recorded on 6in base maps, but in his later work he used the 1922 edition of the 25in Ordnance Survey Map (Beswick and Merrills 1983, 17); here, as in his work on Sheffield Castle, his training as a surveyor clearly influenced his archaeological practice. Unfortunately, despite the hope expressed by Beswick and Merrills $(1983,17)$ that Butcher's work on Sheffield Castle 'may eventually be published', this was not to come to fruition until the present volume.

\section{Sheffield Castle in 1958: the threat of post-War redevelopment}

In the post-War decades the threat to archaeological remains in Britain, especially in cities, was severe (Biddle 1972, vi). Reconstruction and redevelopment, including major infrastructure projects (such as city ring roads), dramatically altered, and in many cases obliterated, the topography of medieval towns and damaged or destroyed the archaeological evidence for human activity within them. This was as true of Sheffield as it was elsewhere, most famously London, where between 1946 and 1962 the Roman and Mediaeval London Excavation Council, led by Professor W. F. Grimes, despite some supposedly 'valuable links' with individuals in the City, managed to raise only $£ 46,000$ to record the destruction of the city’s archaeological heritage (Shepherd 1998, vii; Gerrard 2003, 95-6). As Barri Jones $(1984,122)$ notes, 'the scale of its financial support [was] wholly inappropriate to the archaeological problems posed by the City of London'. In London, as in Sheffield, those linked processes of reconstruction and destruction did not come to an end immediately after the War (contra Jones 1984, 20), and, in Sheffield too, very limited resources were available to counter this threat to its medieval heritage. As Stuart Bryant and Jan Wills $(2016,4)$ point out, during this period archaeological intervention, even on sites threatened with destruction by development/regeneration, was by no means guaranteed. In many, perhaps most, cases, any response to such threats was dependent on voluntary effort and good will, on 'tolerant developers allowing access to sites in advance of the commencement of work?. More typical than not is the situation described by Barri Jones $(1984,48)$ for Perth (Scotland) in 1974, in which requests to gain archaeological access to an important site prior to development came to nothing despite the fact that all that was being asked was 'simple access for observation by persons who were adequately insured and professionally competent'. The Minister of State, in a reply to Perth Civic Trust, made the position clear - if the developer cannot be persuaded to allow time for archaeological examination of a site no power exists to compel him' (Jones 1984, 49; Biddle 1972, vi).

In comparison, the situation in Sheffield in 1958 seems relatively benign. Leslie Butcher wrote several accounts of the process which led to him being asked to record the structures and strata encountered in the course of excavation of the foundations for the new Castle Market building (Butcher 1972a; 1972b; 1972c; 1961; Figure 4.5). Although they vary slightly, these accounts are consistent in reporting that Butcher was 'appointed'

or 'instructed' by the City Architect, (John) Lewis Womersley (Figure 4.6), to record 'all structures of archaeological interest' found during those excavations, and that John Bartlett 'undertook the recovery and conservation of loose finds' (Butcher 1972b, 2; 1972c, 14; 1972a, 5; Nick Butcher pers. comm.). 


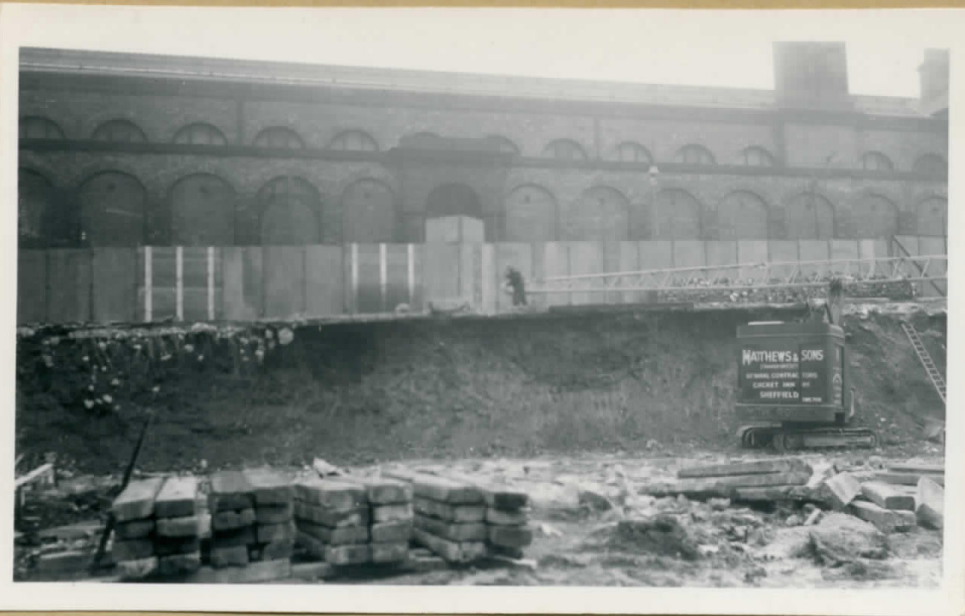

15) Subsid diteh, Exchange At, hue 8.

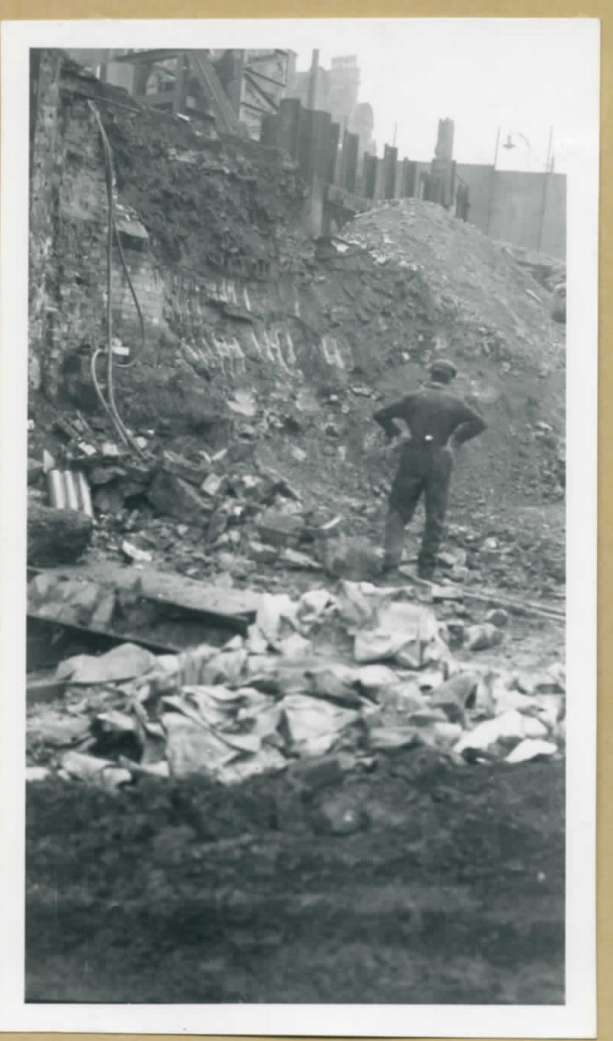

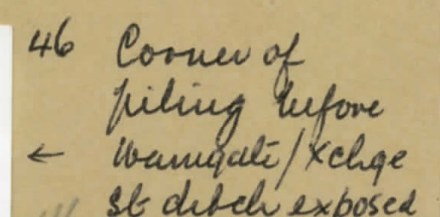

St ditch exposed

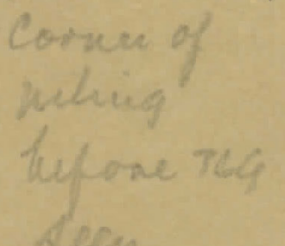

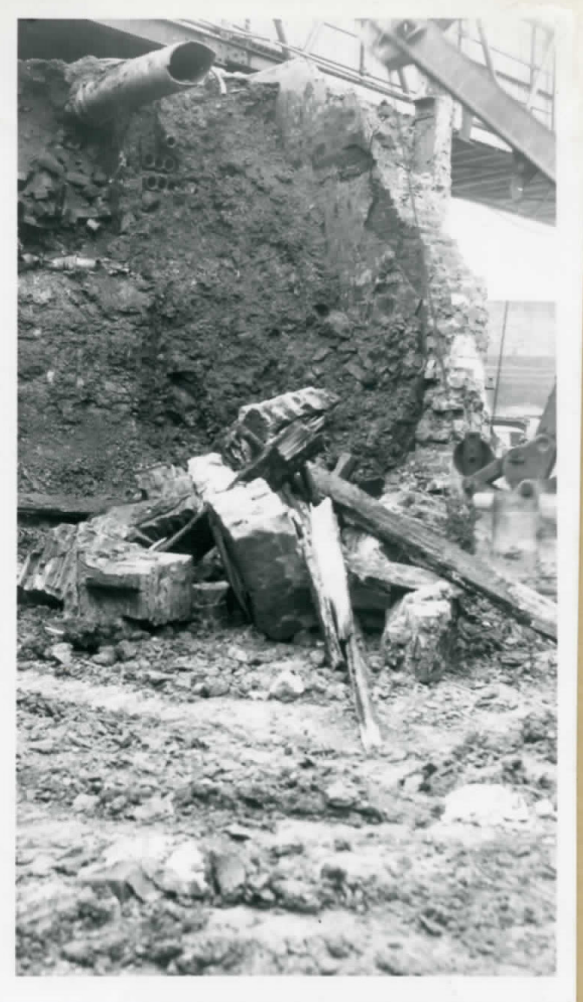

47 Filung hehind $B$ of iet. wall appeas b thane canced away upfer pait of slope of woat seen in T.H. C (See i7)

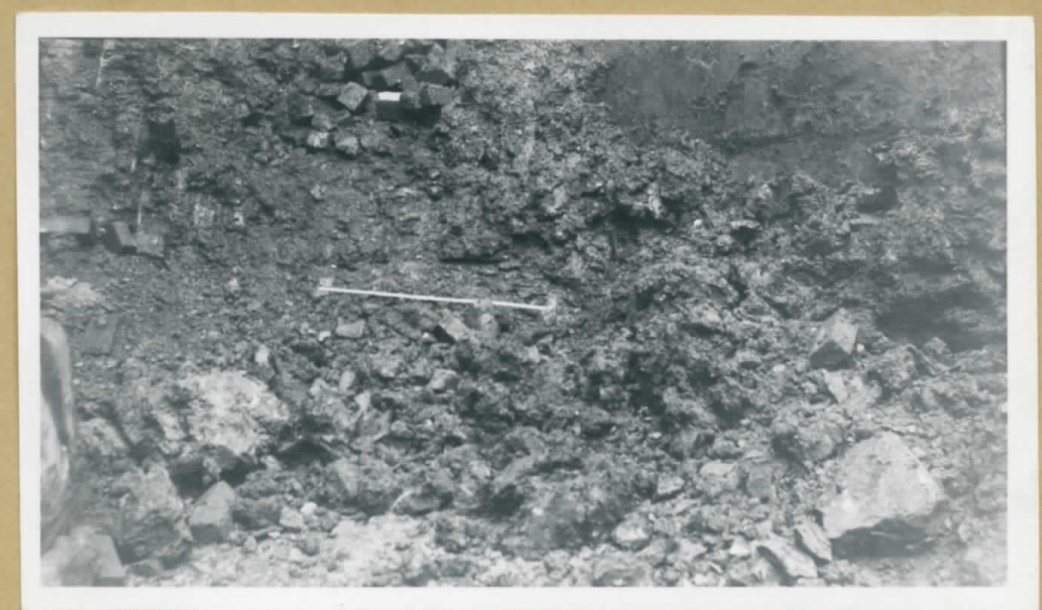

$48 \uparrow$ as 47, latũ.
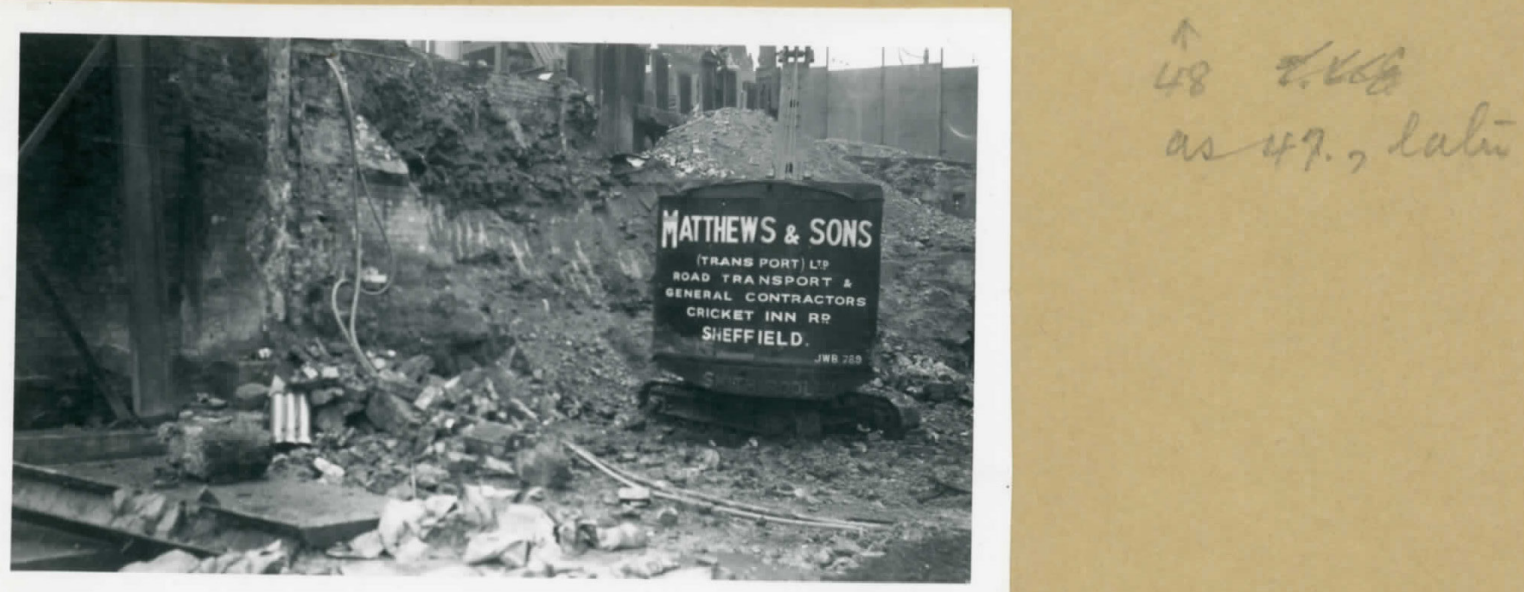

45. Ces 46.26 
The impression that the need for an archaeological input was recognised, and welcomed, at the highest level among those who planned and delivered the Castle Market project is confirmed in the details of some of Butcher's papers. In a handwritten account he stated that Womersley appointed him to the task 'as a result of representations' (Butcher 1972b, 2). One might suspect that those 'representations' were made by the Hunter Archaeological Society, of which Butcher was a member, and which had played such a pivotal role both in securing Armstrong's involvement in the excavations of the late 1920s and in preserving the remains uncovered (see Chapter 2). Had it been them, however, we might have expected Butcher to mention this in a lecture on the excavations which he delivered to Hunter Society members on $10^{\text {th }}$ January 1961 - especially given that a report on the lecture in the next day's Sheffield Daily Telegraph ('New light', 1961), told readers that Butcher had 'recorded the excavations for the corporation and the society' (emphasis added). Instead, in the handwritten text of this lecture, he singled out for thanks 'the council committees \& chief officers of the Corporation who between them decided to have a record and appointed me to do it' (Butcher 1961, 8), suggesting, perhaps, that the impetus (and the 'representations') came from 'high up' in the local authority.

While the decision of the Corporation and the City Architect to make a record of the archaeology on Castle Hill was clearly not driven by any legal requirement to do so, it equally might not have been entirely the product

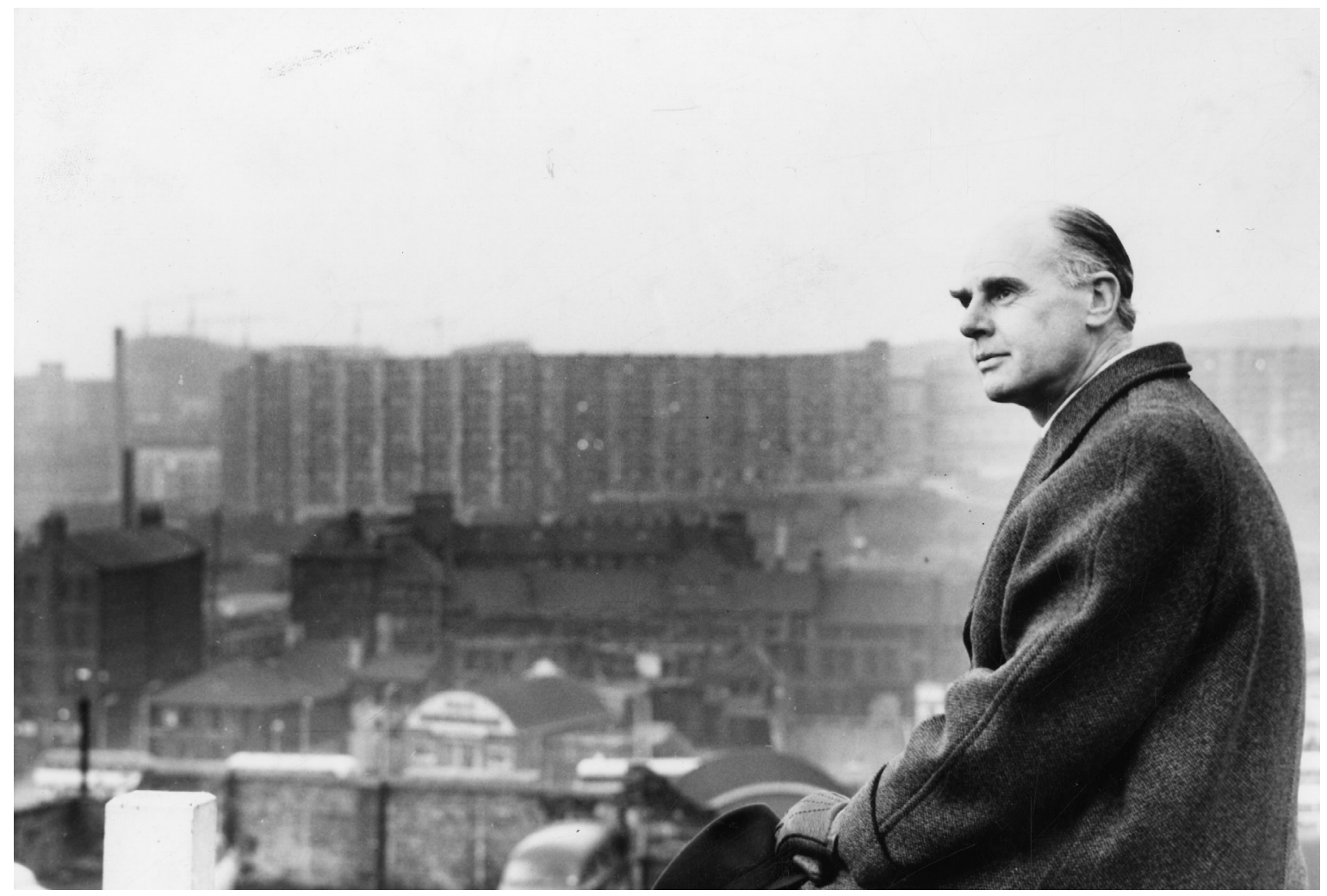

Figure 4.6: J. Lewis Womersley, Sheffield City Architect (1953-64). He was responsible for the building of Castle Market on the site of Sheffield Castle and the high-rise Park Hill and Hyde Park flats on the edges of the former deer park. The Hyde Park flats can be seen on the horizon, in a photograph taken in 1964. With thanks to www.picturesheffield.com (s34943).

Figure 4.5 (page 112): Photographs taken during building work on Castle Hill in the late 1950s/early 1960s. These show the circumstances in which Leslie Butcher and members of the City Museum were working to record archaeological remains. These photographs were all taken at the corner of Exchange Street and Waingate, and the top left photograph shows the pair of ditches that he recorded there in the section. Courtesy of Museums Sheffield. 
of a desire to uncover and understand the city's heritage. From Armstrong's (1930) published account, council records, and the memories of those involved, there will have been awareness of the constructional difficulties encountered by those who built the Brightside and Carbrook Co-op building in the late 1920s, caused by the presence both of substantial stone structures and deep, waterlogged moat deposits. In a telling comment in the typescript of a paper he was preparing for publication in the early 1970s, Butcher reveals that his involvement began even before excavations started on site; he was asked by Womersley ' when design work started on [the new Castle Market building] to assist in defining the shape and extent of the moat for design and contract purposes' (Butcher 1972a, 5, emphasis added). Thus, in contrast to what seems to have been happening in other parts of the country, those involved in creating Sheffield's new market building drew on Butcher's considerable archaeological experience not only to record the remains of the past but also to assist in the pre-construction, design phases of the future building.

This spirit of collaboration continued during the construction process, with Butcher (1972a, 6) emphasising the 'interest, cooperation and assistance of those primarily concerned with building the market' (also Butcher 1972c, 14). This extended to changing construction methods to facilitate archaeological recording. Nick Butcher (pers. comm.) recalls that his father was instrumental in persuading the contractor to use handtimbered foundation shafts at a time when piling was increasingly the norm. This decision was critical in allowing detailed recording and the recovery of a wide range of artefacts. Indeed, in one of his handwritten accounts, Leslie Butcher thanked the Markets Committee, 'the contractors, and the City Architect for supporting the change we advocated in the redesign of the chamber protecting part of the gate structures' (Butcher 1972c, 14, emphasis added). He provided the audience at his Hunter Archaeological Society lecture with further details. Having uncovered the foundations of the towers, the gatehouse forebuilding, and the edge of the inner face of the moat, 'I pressed for these new discoveries to be left permanently open \& both the City Architect, contractor and all concerned finally agreed to lower the sub basement floor a little further' (Butcher 1961, 29). Butcher, therefore, was not only involved, as an archaeologist, in the pre-construction phases of the Castle Market project; he also influenced the mode of construction and the final form of a part of the building - the developers and contractors were evidently willing to listen to him.

Among the details of Butcher's accounts, however, are signs that not all was 'plain sailing. For example, might not the fact that, in the course of his lecture to the Hunter Archaeological Society, he thanked Andrew Derbyshire, the project architect, for 'much sympathy' (subsequently edited to 'understanding \& help') suggest that he too had experienced something of the frustration (and perhaps resistance) which Armstrong records of his dealings with those building the Co-op? Furthermore, Butcher (1972a, 6; 1972c, 14) made a point of noting that during the recording of the archaeological remains on Castle Hill 'lay assistance was not officially encouraged. There were clearly limits to the level of archaeological presence acceptable on site, and (beyond Butcher and Bartlett, and some colleagues from the Museum) this seems to have been confined to those who assisted with photography (Butcher 1972c, 14). There are implications in all this about public access to the city's past, with no sense here that the archaeological remains belonged to 'the people' of Sheffield as part of their patrimony and heritage - and this at a time when community involvement, led by the Hunter Society, in recording (and preserving) that heritage was flourishing (see above and below, Section: John E. Bartlett, the City Museum and the flowering of local archaeology; also Chapters 7 and 9 for how much has changed in this respect since 1958).

Despite the comparatively effective collaboration between archaeologists and developers, in terms of control, finance and resources, the former were still very much second-class (and impoverished) citizens. Butcher's friend Cyril James assisted with photography, and 'took score upon score of colour photographs at his own expense \& in his own time' (Butcher 1961, 8, emphasis added). It is not evident from his written accounts how Butcher's own time and effort were funded - and, to judge from the large number of sections, plans, isometrics and other reconstructions he produced, he spent a vast amount of time on the project. We need to remember that, like his predecessors Armstrong and Himsworth in the role of recording the castle remains on a site 'under active commercial excavation' (Butcher 1972c, 4), he was not a professional archaeologist - there were still very few of them. He had a full-time job as a surveyor, and his son Nick (pers. comm.) reports that his father's involvement on the castle site during the construction process was 'mostly confined to his lunch breaks', with his office conveniently located nearby in Fitzalan Square. Although he was only 12 when the excavations began, Nick well remembers 'our daily discussions of his observations from each day's lunchtime inspections of the foundation shafts'. So, although Womersley may have 'appointed' him to the task of recording the castle 
remains, it seems that neither was he 'seconded' to that role nor were significant (any?) resources placed at his disposal to help him complete the task. As Nick Butcher (pers. comm.) told us, 'I am not aware that ... he had any in-work time allotted to this work. Rather my impression was that if he was a little late returning from his "dinner break", due to some especially interesting situation, he had backing from a very high level'. In this context it is very telling that, at the beginning of his 1961 lecture to the Hunter Archaeological Society, Butcher thanked the 'senior members of the OUR Committee who produced cash when my funds ran low' (Butcher 1961, 8, emphasis and correction in the original). Perhaps Andrew Derbyshire's 'sympathy' was for the straitened circumstances in which Butcher had to work?

\section{John E. Bartlett, the City Museum and the flowering of local archaeology}

We know much less about John Bartlett's involvement in the Castle Hill excavations that began in 1958 (Figure 4.7). He is not mentioned at all in some reviews of the archaeology of the site (e.g. Parsons 1997, 1; Belford 1998) and only once in others where he is merely noted as having assisted Butcher (e.g. Davies and Willmott 2002, 6; Richardson and Dennison 2014a, 55). This negation of Bartlett's involvement is, to some extent, understandable. First, unlike Butcher, he did not produce any written account of the project or of his involvement in it - so we simply know much less about what he thought or did. Second, his involvement was comparatively brief as he left Sheffield on $1^{\text {st }}$ March 1959 to take up an appointment as Director of Museums at Kingston upon Hull (East Yorks) (Museums Sub-Committee 1960). However, we have established that his participation was as part of a partnership with a defined and accepted division of responsibilities: Butcher, with his extensive surveying and archaeological field experience, and background in geology, took charge of recording and mapping the structures uncovered and the local topography; Bartlett, also an experienced field archaeologist but with a museum background, took on responsibility for the finds (Butcher 1972a, 5-6; also 1972b, 2; 1972c, 14). It is not clear from the archival material who asked Bartlett to take on this role, but it was probably the Museum Director, H. Raymond Singleton. Moreover, as we will see, Bartlett was one of the driving forces behind local archaeological enthusiasts, and had worked closely with Butcher for some years through their involvement in the Field Research Section of the Hunter Archaeological Society.

Bartlett was notably more visible than Butcher in the early newspaper reports on this phase of the uncovering of the castle. On $25^{\text {th }}$ April 1958 the Sheffield Daily Telegraph reported that 'Sheffield City Museum authorities have been carefully watching [the excavations], since the market work started some months ago' (Hopkinson 1958a), and on $2^{\text {nd }}$ May noted that 'Mr John Bartlett, Deputy Director of Sheffield City Museums, is watching the site excavations on the Museums' behalf' (Hopkinson 1958b). In neither case is there any mention of the involvement of Butcher or the Sheffield Corporation. This just might be a product of the personalities involved, with Butcher being somewhat 'retiring' and Bartlett not averse to the limelight (Pauline Beswick, pers. comm.; Armstrong 2001, 4) - Nick Butcher (pers. comm.) recalled that 'my father was not a committee man and did not fit into administrations easily. Rather he preferred to work alone or rather with his close group of associates'. Butcher (1972a, 6) described his work with Bartlett as a 'very enjoyable collaboration', and his son Nick (pers. comm.) told us that it was his impression that 'the relationship was one of mutual respect with the work undertaken being collaborative and complementary, rather than overlapping'. He also said that he thought that his father 'gradually drifted away' from the Hunter Archaeological Society after John Bartlett left the Museum, perhaps confirming our impression of the close relationship between the two. Expanding on the working relationship between his father and the Museum staff, Nick provided some fascinating insights into the practice of archaeology on a mid-20th-century construction site:

My father's role was principally as surveyor producing [foundation-]shaft stratigraphy sections, finds locations (at least in terms of depth) and measuring up the castle foundations and moat profiles to the extent they were revealed. My understanding was that each day's moat diggings (by one man) was stacked off to one side or in a series of kibbles ${ }^{18}$ by the contractor and worked through by the museum staff [presumably including Bartlett] and volunteers by the next day (Nick Butcher pers. comm.; Figure 4.8).

${ }^{18}$ The word 'kibble' derives from mining - a large wooden or (later) iron bucket, for conveying ore or rubbish to the surface' (O.E.D.). 


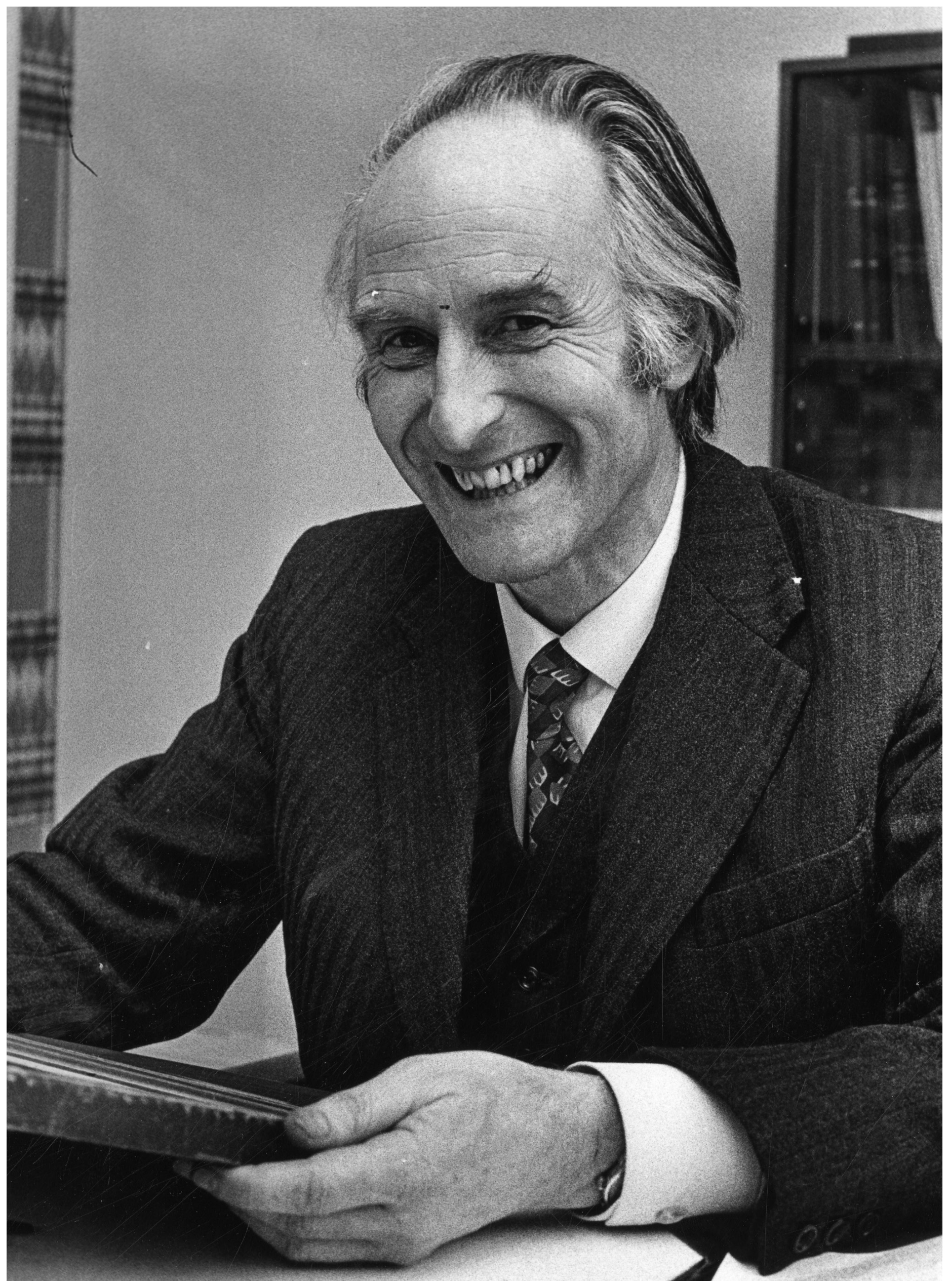

Figure 4.7: John Bartlett. Photographed in 1972, after he returned to Sheffield from Hull Museum to take up the post of Director of the City Museum. Courtesy of Sheffield Newspapers Ltd. 


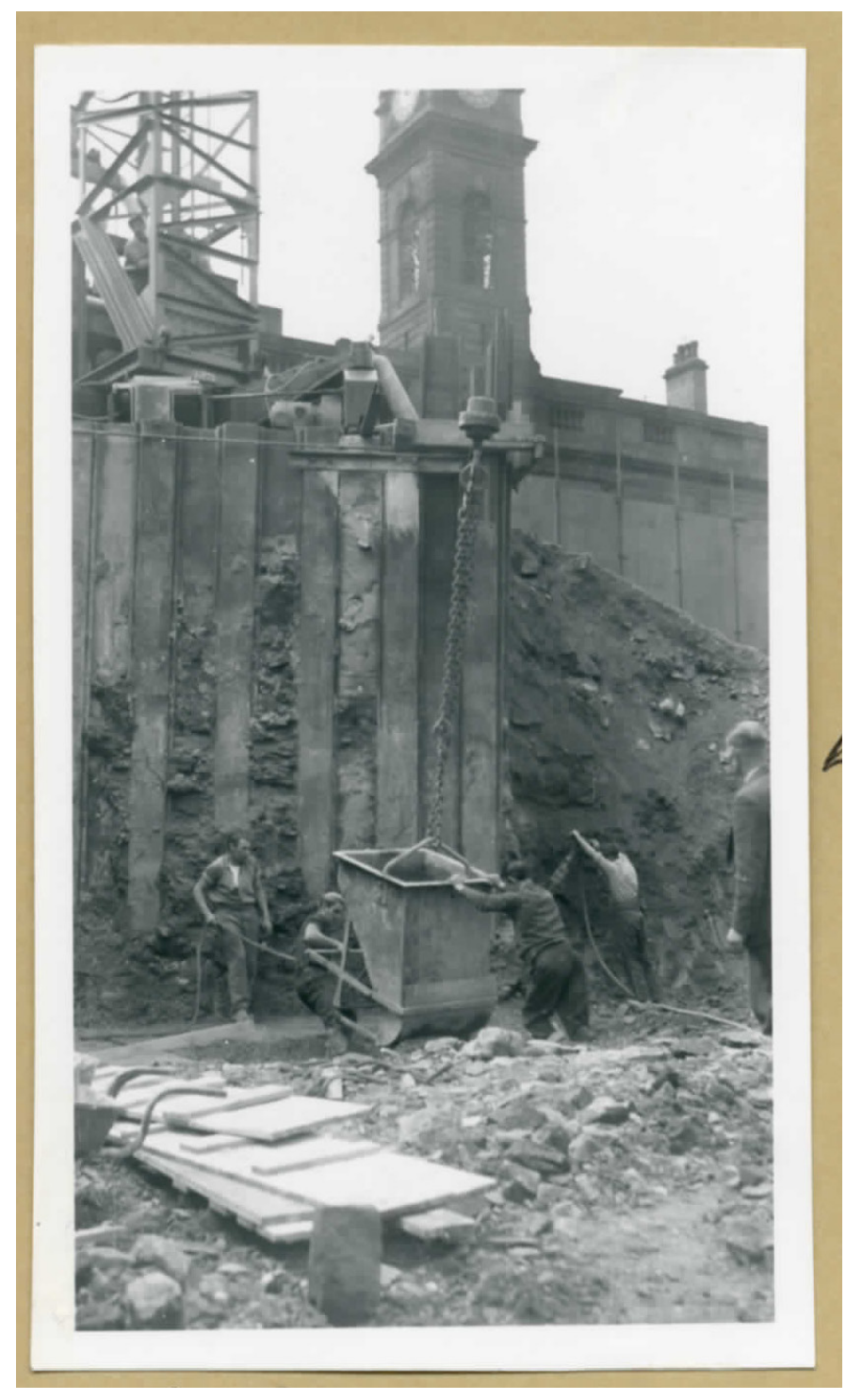

Figure 4.8: Workmen filling a bucket - or kibble as it was known in mining parlance - during construction work on Exchange Street. Courtesy of Museums Sheffield.

It is clear that, before his departure for Hull in early 1959, John Bartlett was central to overseeing, and disseminating information about, the castle excavations. His involvement was also critical in making the discoveries on Castle Hill accessible to the people of the city and region. In 1958-59 Sheffield City Museum planned to reorganise its Saxon and medieval material into three new displays - showcasing Anglo-Saxon jewellery and metalwork (including the famous 7th-century helmet from Benty Grange (Derbs)), medieval pottery and sculpture (including material from Beauchief Abbey), and medieval metalwork, respectively. However, while these displays were being created, 'the excavation of the site of Sheffield Castle ... brought to light sufficient new material, mostly of mediaeval date, for a fourth case of items illustrating that particular period in the city's history' (Museums Sub-Committee 1960; Figure 4.9). At a time when direct lay participation in the excavation and recovery of archaeological material was not 'encouraged', yet visitor numbers to the Museum were growing (Museums Sub-Committee 1960, 5), this display would have been as close as many people were able to come to the process of discovery then unfolding as the new market building was erected over the site of the castle.

Finally, it is important to highlight that Bartlett, through force of personality and passion for the past, acted as a catalyst for the study of archaeology in Sheffield. Indeed, it was his arrival at the City Museum in 1954 that 
saw the Scheme for Archaeological Research developed by Preston and Butcher finally begin to have an impact on the local archaeological fraternity, as he facilitated access to the Scheme's index at the museum. Moreover, he was instrumental in encouraging the creation of a new Field Research Section of the Hunter Archaeological Society in early 1955, becoming its Field Director; a series of excavations was then organised to train local enthusiasts directed by Bartlett, Preston and Butcher, the latter working at Wharncliffe and Grenoside (Beswick 1997, 105-6). Recollections by those who knew Bartlett in his role as Director of Hull Museum provide insights into both his character and his impact on people. Peter Armstrong $(2001,4)$ remembered him as 'an inspirational character' with an 'unstoppable combination' of 'irrepressible energy and irresistible persuasiveness'. He is said to have possessed a 'uniquely flamboyant, close-up style ... able to charm you into feeling that for that one receptive moment nobody else in the whole universe mattered more than you'. Such was the force of his personality that he attracted interested people to him, and made things happen. Thus, an editorial in the East Riding Archaeological Society News, celebrating the Society's 25th anniversary, suggested that

it was the drive and enthusiasm of John Bartlett, the newly arrived Director of the Museum, who was the catalyst that brought the Society into existence [in the autumn of 1960] and stimulated so much interest in the subject. For there were a number of others already immersed in archaeology at that time, but one feels that a vital spark was lacking (Hampel 1985, 1).

There is evidence that Bartlett had had the same impact in Sheffield prior to his move to Hull. Nick Butcher (pers. comm.) told us that his father's interest in archaeology had been sparked in the early 1950s when, as a surveyor for a road project, he cut through the 'Roman Rig' east of Wincobank Iron Age hill fort in north-east Sheffield, and he subsequently attended lectures organised by the Hunter Archaeological Society at Sheffield University, and at the Museum by Singleton and Bartlett. Through these classes with Bartlett, Butcher met Cyril James, an engineer with 'a very good knowledge of the limestone area of Derbyshire and its lead mines and caves'; James was crucial in introducing Butcher to the archaeology of Derbyshire, not least because he had a car, since Butcher never drove (Nick Butcher pers. comm.). Moreover, as we saw earlier, James took many of the photographs of the castle excavations preserved in the Butcher archive, and along with his wife Pat was among those who retrieved finds from the kibbles of sediment excavated from the foundation shafts. James, Butcher, and Gordon Hunter, one of the latter's work colleagues, 'spent most Thursday evenings in summer surveying the Bronze Age field systems of the gritstone dipslopes/edges west of Sheffield' (Nick Butcher pers. comm.). They also worked with Freddie Preston to systematically survey the landscape around Sheffield, contributing to the Hunter Index (Jones 2012, 35). Inspired by his classes with Bartlett, Butcher went on to teach his own archaeology classes with the Workers' Educational Association, which were taken by Gordon Hunter and another later collaborator Graham Makepeace along with members of the Peak District Mines Historical Association. Bartlett looks to have been one of the inspirations, if not the inspiration, behind this remarkable flowering of archaeological activity in Sheffield in the late 1950s, which undoubtedly contributed much, in terms of personnel and skills, to the recording of Sheffield Castle.

It is easy to overlook the importance and contribution of local archaeological societies, and of the meetings and activities they have been organising for a century or more, but it is clear that without their input much more of the British archaeological record would long have been lost, especially in the wake of 20th-century urban development. Today it is the contributions of metal detectorists, recording their finds through the Portable Antiquities Scheme, that tend to come to the fore when professional archaeologists acknowledge the input of amateur enthusiasts (Lewis 2016), but this is just the latest manifestation of the significance of ordinary people in shaping the archaeological record. It is, indeed, surprising that so little scholarly attention has focussed on the work of local archaeological groups in Britain, given the extensive discussion of the importance of archaeologists acknowledging communities and their beliefs and sensitivities about their heritage in many countries, and of working together with communities to use archaeology for social benefit in the modern world (e.g. Sabloff 2008). Throughout this book we have been demonstrating that the history of archaeology matters just as much in northern English cities like Sheffield as it does in the more glamorous, and sunny, places on which many archaeologists prefer to focus their efforts.

Figure 4.9 (page 118): Finds from Sheffield Castle. This new display was created following refurbishment of Sheffield City Museum in 1958-59. Courtesy of Museums Sheffield. 


\section{New foundations for Sheffield Castle}

Although the plans for the new market building meant that the stanchion supports, and thus the excavations, largely avoided those of the late 1920s Co-op structure, and had deeper foundations, Butcher later observed that 'with few exceptions, the ground gone over in 1958-1960 is that gone over in 1927-30', and lamented that he was thus denied the 'thrill of first discovery' experienced by Armstrong (Butcher 1961, 6, 11, 29; also opening quotation of this chapter). Yet, the fact that the new foundation works overlapped, and in some cases extended beyond, the earlier trenches, presented Butcher with the opportunity both to check the recording undertaken by Armstrong and Himsworth and also to record more of the remains in the areas that had been investigated before, particularly parts of the gatehouse, moat and courtyard surfaces.

Perhaps unsurprisingly, given the brief set by Womersley, the majority of the unpublished records of the castle in the Butcher archive focus on the (constructionally problematic) south moat and the gatehouse area, where some of the foundations and service trenches were dug by hand, providing the opportunity to record the excavated features in detail (Butcher 1972a, 5-6; 1972b, 18; Davies and Willmott 2002, 6). Butcher recorded each of the foundation trenches and pits meticulously: 'all four sides of each stanchion base, each side of each trench \& so on ... were measured fully ... all were photographed in bl \& white, \& some in both bl \& wh and colour' (Butcher 1961, 12, 18; also 1972a, 24; Figure 4.10), and the location of each photograph marked on a plan of the site (Ove Arup \& Partners and Butcher 1957; Figure 4.11). Where features could not clearly be seen they were usually omitted from his drawings rather than projected; this is a practice that he had long since adopted in his field survey (Beswick and Merrills 1983, 17).
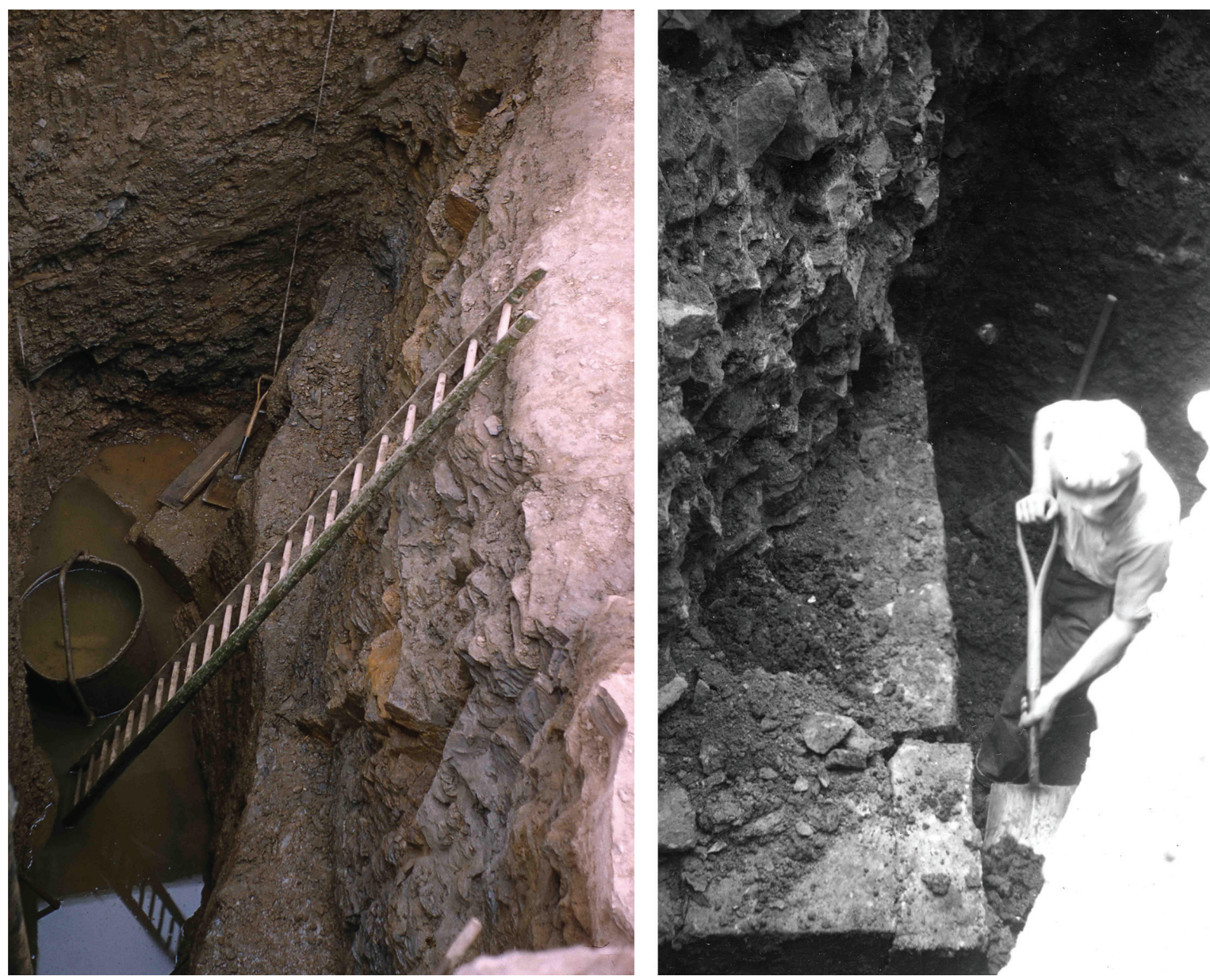

Figure 4.10: Photographs of foundation shafts taken on site in the late 1950s. The Butcher archive contains a wide array of both colour and black and white photographs, taken by Cyril James, Ray Newton and Leslie Butcher. Courtesy of Museums Sheffield. 


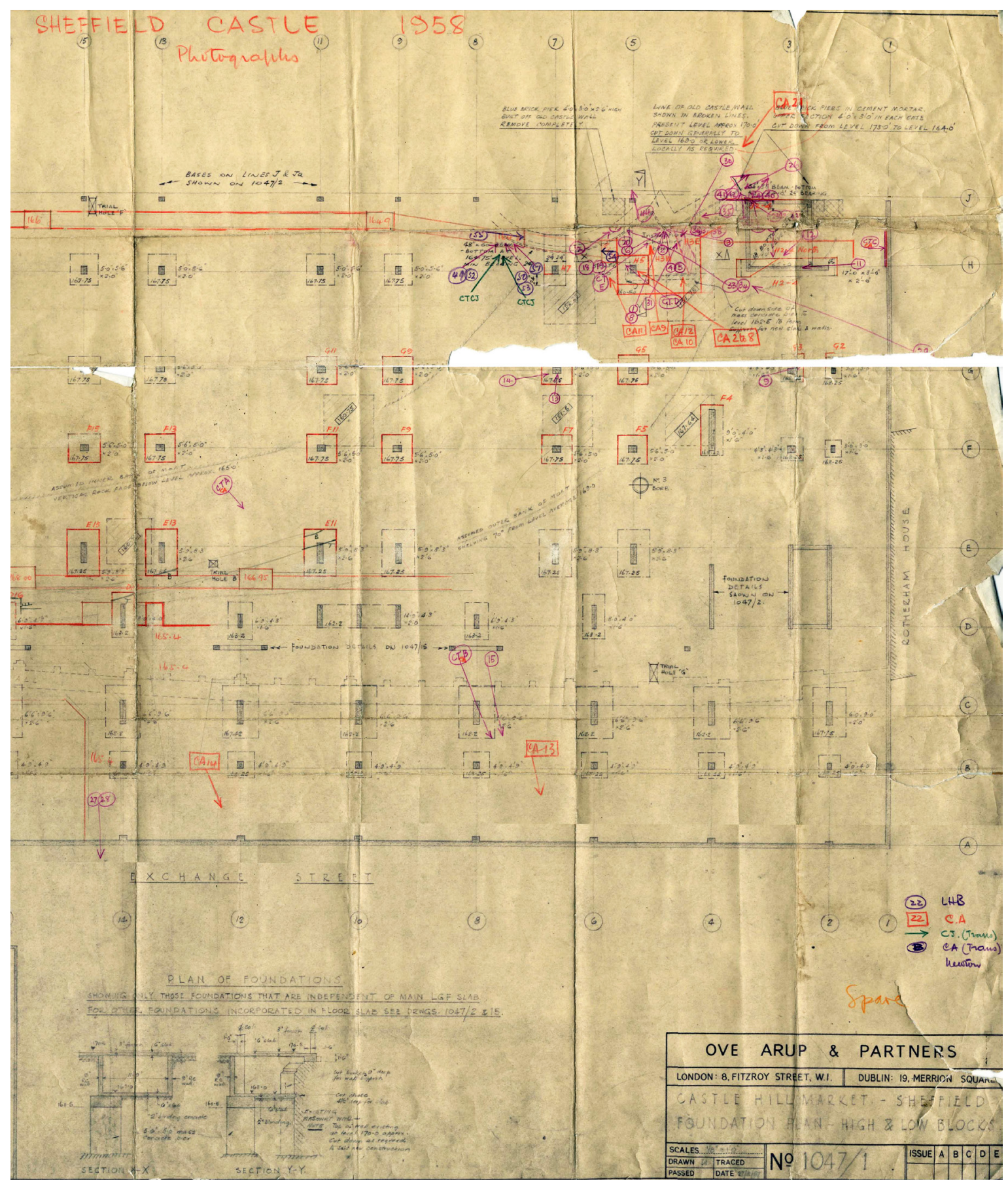

Figure 4.11: Leslie Butcher's record of the photographs taken in the area of the gatehouse. The photographer and the direction from which the picture was taken, are also marked on this copy of the Ove Arup \& Partners foundation plan for Castle Market. Courtesy of Museums Sheffield.

The excavation and recording of discrete squares would have been familiar to Butcher (Figure 4.12). What evidence we have for his own archaeological practice, albeit on rural sites, suggests that he deployed the same box system (the so-called Wheeler-Kenyon method) discussed in Chapter 2. This is seen most clearly in the posthumous publication of his work at Whitley, Wharncliffe, which was excavated (c.1958-60) through a grid of $20 \mathrm{ft}(c .6 \mathrm{~m})$ squares, separated by $5 \mathrm{ft}(1.52 \mathrm{~m})$ wide baulks (Makepeace 1985, fig. 4; Figure 4.13). As we saw in Chapter 2, the aim of the box system was to effect the excavation of the whole site while at the same time 


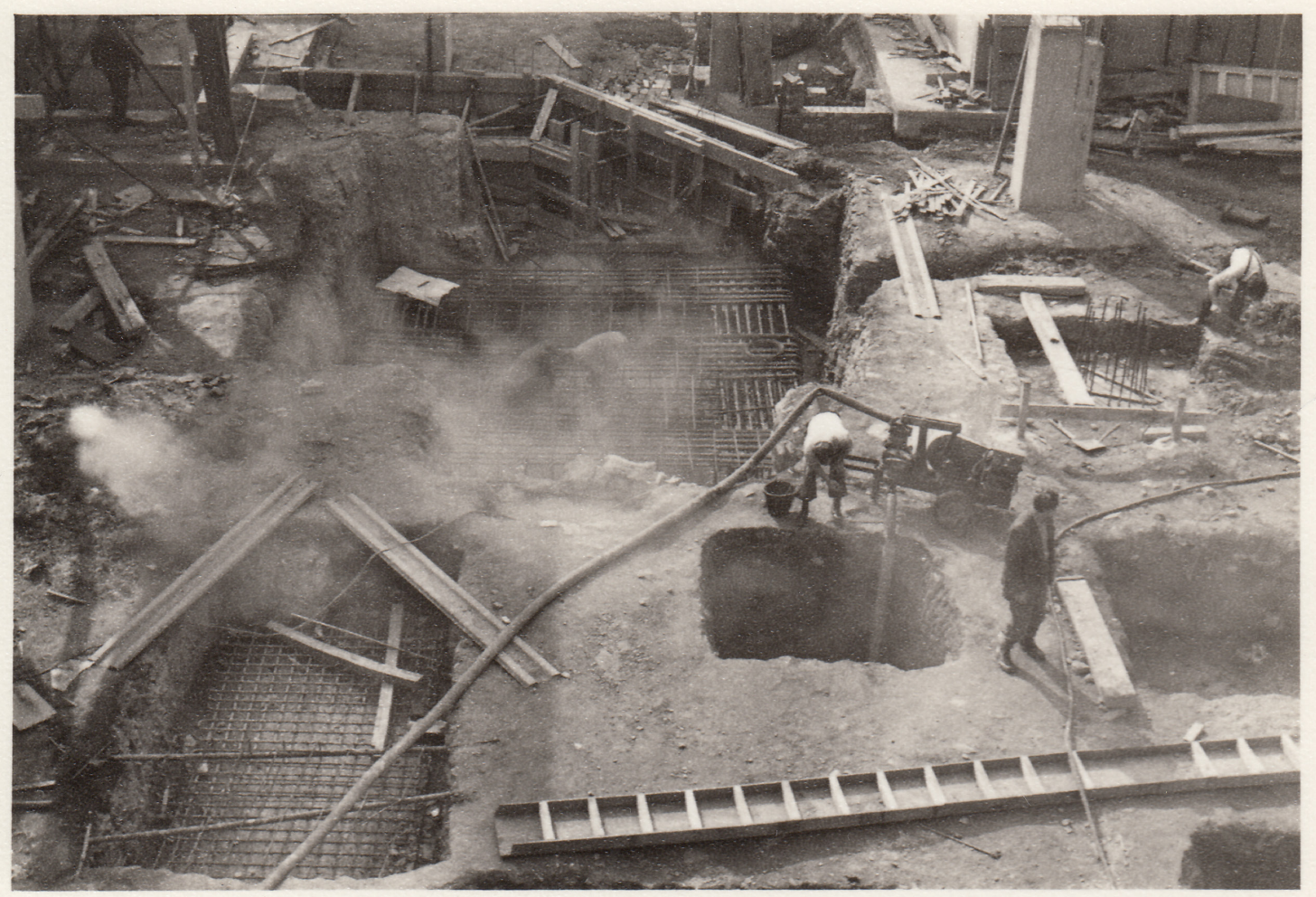

\section{SEP 1958}

Figure 4.12: Foundation shafts being dug by construction workers. This is the 'excavation grid' that Butcher recorded. Courtesy of Museums Sheffield.

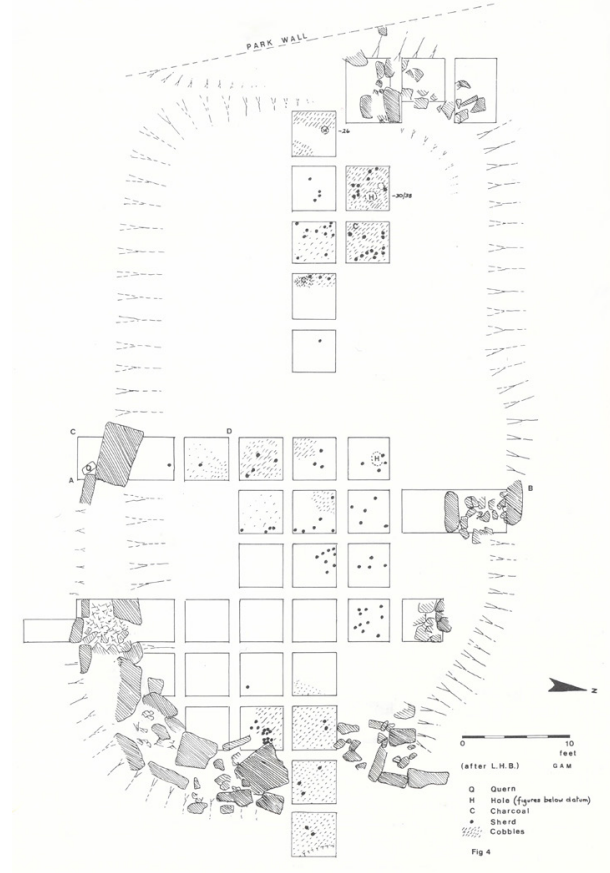

Figure 4.13: Plan of the excavation grid used by Butcher at the Romano-British settlement at Whitley, Wharncliffe (South Yorks). From Makepeace 1985; reproduced courtesy of the Hunter Archaeological Society. 
retaining chronological control through multiple sections. At Whitley, Butcher achieved this not by removing the baulks (as Wheeler recommended) but by 'joining together' a series of sections to create a profile across the site (Makepeace 1985, fig. 5). As Gavin Lucas $(2001,52)$ notes, by the beginning of the 1960 s very little had changed in terms of excavation technique from the time of Wheeler, and Martin Carver $(1987,105)$ links the prevalence in British urban archaeology of 'the efficient Wheeler system of standing boxes' to the 'sondages' long used on the much more ancient urban sites of the Middle East. So, like Armstrong, Butcher would have been very familiar with the practice of viewing the archaeology of the castle site through a grid - of the foundation shafts excavated for the market buildings. The shallow stratigraphy of sites like Whitley would not have prepared Butcher for the deep sections of these foundation shafts, but no doubt his surveying and roadbuilding experience did. And, as at Whitley, at Sheffield Castle too he 'joined together' the sections of adjacent foundation shafts to create profiles across large areas of the site (see Chapter 5).

In contrast, the foundations for the west side of the new building along Waingate were driven piles (Butcher 1972a, 24; n.d. (g)), which provided fewer opportunities for observing archaeological remains, although Butcher was, nonetheless, able to record the position of the 'vertical and sloping parts of the inner rock-cut face' of the moat and its depth (Butcher 1972a, 24; 1958-62b; 1958-62d; 1958-62e). The limited interventions during construction work on the east side of the site were mostly service trenches and manholes, although one of these revealed part of the moat (Butcher 1958-62d). During alterations to the east wall of the 1930s market building, Butcher (n.d. (r)) was able to draw sections of the exposed archaeology, which revealed a clear sequence of deposits associated with the courtyard surfaces and building that had been recorded by Armstrong $(1930,12,20-1)$, as well as deposits immediately behind the retaining wall overlooking Castlegate and the Don, and the natural topography of the site. The demolition of the buildings along Exchange Street was also monitored, revealing further ditches outside the moat around the inner courtyard (Butcher 1972a, 9).

\section{Making sense of the archaeological record}

Only a single short account of the late 1950s work at Sheffield Castle was ever published, in the annual roundup of excavations in Britain and Ireland for 1959 in the journal Medieval Archaeology. It is reproduced here in full:

Builders' excavations watched by L. Butcher have allowed re-examination of the moat and gatehouse first revealed in 1927 (A. L. Armstrong, 'Sheffield Castle, Trans. Hunter Archaeol. Soc., IV (1929-30), 7-27). A SW. angle and N. return in the moat (not observed 1927) have been defined. The moat, perhaps $35 \mathrm{ft}$. wide at original ground level, splays inwards to $18 \mathrm{ft}$. in the first 10-20 ft. of depth; below, vertical rock-cut walls carry it to depths between $30 \mathrm{ft}$. and $40 \mathrm{ft}$. Pottery and small finds of the 13th to the 17th century confirm the documented military occupation of the site; a few sherds of coarse heavily shell gritted ware of the late 11th century (Armstrong's 'Saxon') indicate earlier occupation (Hurst 1959, 308).

The focus in this published note was on comparing what had been uncovered with Armstrong's earlier findings, and it is telling that Butcher identified the pottery from the supposed 'Saxon' phase as being of late 11thcentury date, indicating that very early on in his work on the castle he disagreed with the earlier interpretation.

Butcher intended to publish a more detailed account of his work on the castle. In April 1970, he proposed that 'a comprehensive report be made on the known archaeological facts of the area of the Castle and its immediate environs', noting that this could be relatively easily achieved on the basis of the records he had kept during construction of Castle Market and the rebuilding of the Woolworth's building at 34-36 Haymarket just to the south (Butcher 1970). He commenced writing up what he had recorded, and the archive contains various handwritten drafts (Butcher n.d. (a); 1972b; 1972c; 1972d), and a typed copy of that paper dated to around 1972, to be submitted to the Transactions of the Hunter Archaeological Society. The handwritten drafts contain more detail, and he seems initially to have been intending to publish it in two parts - as one draft refers to a 'Part I' and 'Part II' to appear in different volumes of the Transactions (Butcher 1972c, 1, 14-15) - but then seemingly changed his mind, and someone other than Butcher had annotated the handwritten manuscripts with instructions about passages to be omitted (e.g. Butcher 1972c, 15; 1972g; 1972h). The typescript therefore seems to be in the format that he intended to publish his findings and other than a few missing measurements 
looks largely complete. Butcher could not type (Nick Butcher, pers. comm.) and so it was prepared for him, and there are a number of instances of the typist misreading Butcher's handwriting. The typescript summarises the key findings across the site, and provides a list of intended illustrations (Butcher 1972a, 25-7). It reveals that the main focus for Butcher was to determine the date of the earliest phases of activity at the castle, to establish the form and extent of the gatehouse, to trace the position and profile of the moat, and to identify how it was fed with water, a question undoubtedly informed by his background in geology. It also sets out at length Butcher's thoughts on the topography of the site, reflecting his interest in landscape, as evidenced in his other archaeological work. He was clearly far less interested in the people who had occupied the castle; in this respect his approach is very different from that of Armstrong and Himsworth a generation earlier.

The unpublished typescript and handwritten notes reveal that Butcher had studied closely the work of Armstrong and Himsworth, as he summarised their findings, both published and unpublished, and attempted to relate them to his own. Butcher $(1972 a, 1)$ realised that the new work on the site had both 'extended and in some parts corrected Armstrong's "Account", and that while it had largely confirmed Armstrong's views of the stone structures it had, on the other hand, 'the effect of rendering obsolete most of his views of the moat' (Butcher 1972a, 3). In his 1961 lecture, for example, he told his audience 'you will have noticed already on this slide that contrary to ALAs [Armstrong's] surmisal, the moat does not cross Waingate and go under the courthouse but turns northward, barely cutting into Waingate and procedes [proceeds] squarely under the Styring property' (Butcher 1961, 13; see Figure 1.11 for the location of this building, where it is marked as Lenton \& Rusby - Charles P. Styring was an optician there; also Armstrong's plan 1 Figure 3.2). Butcher (1972a, 24) also tells us that he had access to 'not only the late Leslie Armstrong's observations of 1927 and 1929 ... but also [to] records kept by the Clerk of Works during the original 1927 development of the southern part of the site, which Armstrong either never saw, or used very selectively'.

Butcher (1972a, 4) acknowledged use of what he calls 'Himsworth's "Notes on Sheffield Castle", a photographically illustrated typescript', which he says he accessed in Sheffield City Library. His discussion establishes that this was Himsworth's diary, and, indeed, we found a photocopy of it in Butcher's archive, along with two pages of photographs (labelled '1958') from his own excavations, two copies of an Ordnance Survey map of the Castlegate area, on one of which the excavated remains of the castle, the moat and other features are sketched, and two sketches of the same area. Intriguingly, this is not a copy of the version typed out by Harry Lea that we discussed in Chapter 2, as it has been updated to include the content of handwritten annotations by Himsworth on the first typed version; it contains a Sheffield City Libraries bookplate recording that it was 'Presented by Bequest of Mr C. H. Lea July 1965', suggesting that Lea had typed out a second version (Himsworth n.d. (b) and (c)), and that the diary was taking on a life of its own in the history of the castle. Having stressed the importance of Himsworth's 'Notes on Sheffield Castle', Butcher (1972a, 4) went on to emphasise that 'Himsworth's profile of the slope between Castlegate and the Market car park ... is ... the only record we have of what was revealed when the "New Road" was made, and it has proved invaluable. Butcher (1972a, 3) realised the significance of the work of Himsworth to record the remains, some of which was not included in the 1930 publication as we saw in Chapter 3, and also that Armstrong had relied greatly on him when preparing his paper.

While omitted from the typescript, some of his handwritten drafts explain the approach Butcher (1972c, 4) took to the work of his predecessors: 'If the present reporter appears over-conscious of clearing rubble from Armstrong's report \& redressing Himsworth's Notes he trusts that in the process he has revealed \& conserved the soundest parts of each before incorporating them in a new monument to the labours of two pioneers'. Butcher collated the records of earlier work on the site, including the surviving engineers' plans for the construction of the Brightside and Carbrook Co-op building in 1927-30 (Johnson 1927b; 1927c; Davies 1928; Anon. 1922). For example, during the clearance of Chandler's Row (the lane which ran between the slaughterhouses) in July 1930, Himsworth $(1927-40,17)$ had recorded walling near the bank of the River Don, and in his diary had noted that 'a plan was furnished of these by the City Architect', a copy of which is retained within Butcher's archive (City Architect's Department 1930; Figure 5.8). Butcher also drew many new plans which associate the features he encountered with those seen in the earlier investigations and also with the modern buildings in the area. For example, a plan of the gatehouse, forebuilding and drawbridge pier was colour-coded to show the areas recorded by Armstrong (green) and his own new observations (red) (Butcher 1958a; Figure 5.15). Butcher used Ordnance Survey maps and Himsworth's photographs to enable the locations of the 1920s findings to be 'accurately fixed'. This much is to be expected when one considers his posthumously published regional landscape surveys, in which it can be seen that he took a methodical approach to drawing landscape 
features on the 1922 edition of the 25in Ordnance Survey map, often resurveying features as he refined his methods (Beswick and Merrills 1983, 17).

The archive is also invaluable in highlighting an aspect of Butcher's methodology in which he explicitly differed from Armstrong and Himsworth: Butcher placed a greater emphasis on visual recording, through maps, plans, isometric drawings and reconstructions. Indeed, he complained that Armstrong's and Himsworth's observations on the moat were 'unfortunately only recorded in words' (Butcher 1972b, 6), although our analysis in the previous two chapters suggests that Butcher rather overstated his case and misrepresented the work of Himsworth, in particular, given the extensive photographic record created in the course of the 1927-30 work. Nonetheless, it remains true that Butcher's archive mainly comprises drawn, rather than written, records; and that he placed a greater emphasis on the image (both graphic and photographic) than on the word. In particular, his isometric drawings, with deposits and features annotated and coloured, testify to his great skill as a draughtsman and are the most visually striking component of his archive. These are mainly based on his section drawings of the foundation shafts (Butcher n.d. (k)) but also feature the gatehouse and moat (Butcher n.d. (b); n.d. (c); n.d. (d); n.d. (e); Figure 4.14). He produced interpretative drawings including a reconstruction

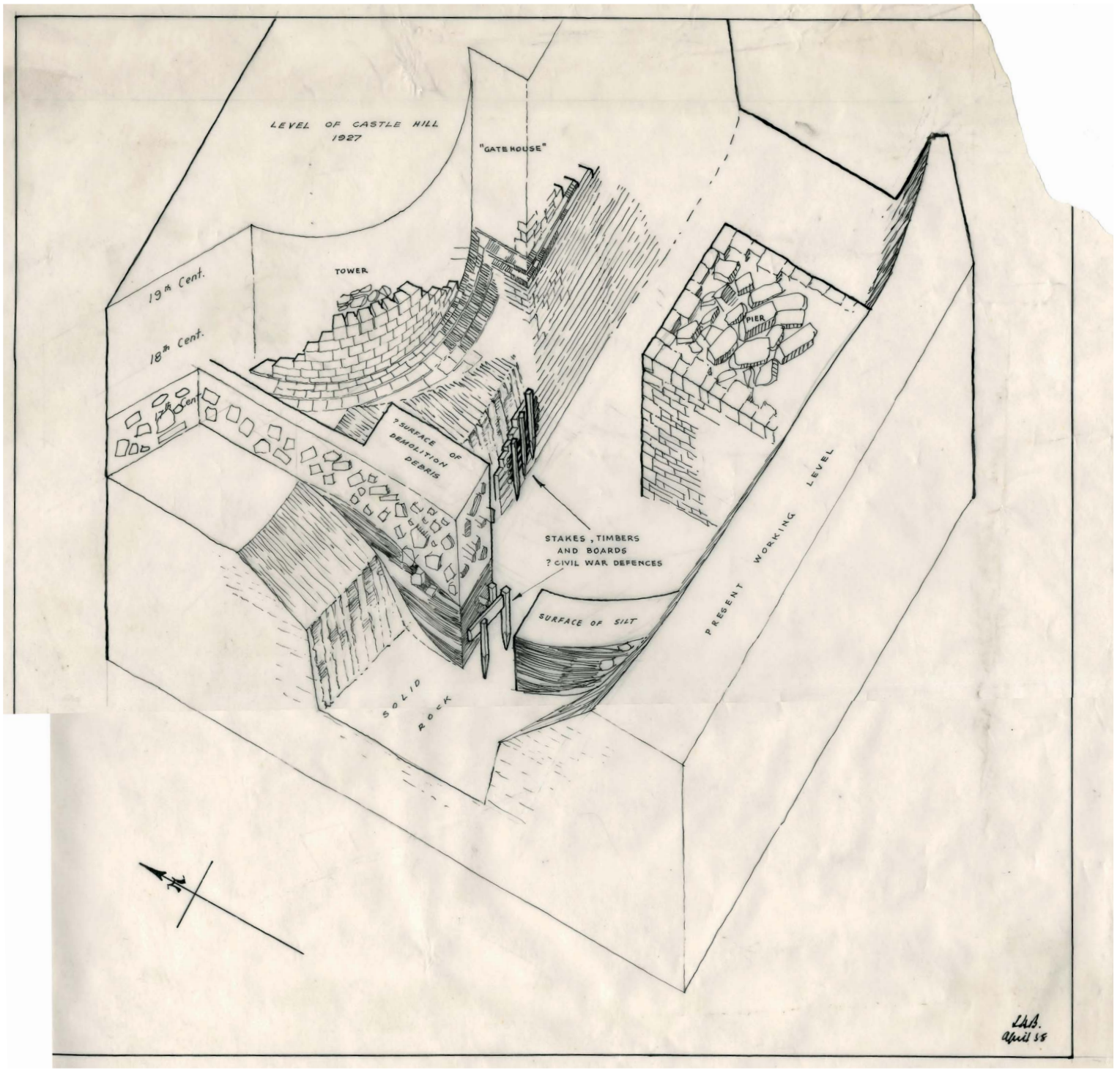

Figure 4.14: Draft isometric drawing of the area in front (south) of the castle gatehouse. Courtesy of Museums Sheffield. 
of the gatehouse (Butcher 1958b; 1958c; Figure 5.18), and a high-quality elevation drawing of the surviving masonry (Figure 5.13), which provides considerably more detail than appears in the drawn and photographic records produced by Armstrong and Himsworth. It is apparent from his lecture text that Butcher regarded his illustrations as an important means of communicating what he had recorded to the general public.

He annotated copies of the 1:1250 Ordnance Survey map (1953) of the Castle Market area showing the position of the gatehouse, the courtyard building, the moat, and the ditches on the south side of Exchange Street (e.g. Figure 4.15; Butcher n.d. (h)), and used the depths of a series of boreholes that crossed the lines of the south and west moat to overlay contour lines showing the underlying topography of the site (Butcher n.d. (i);

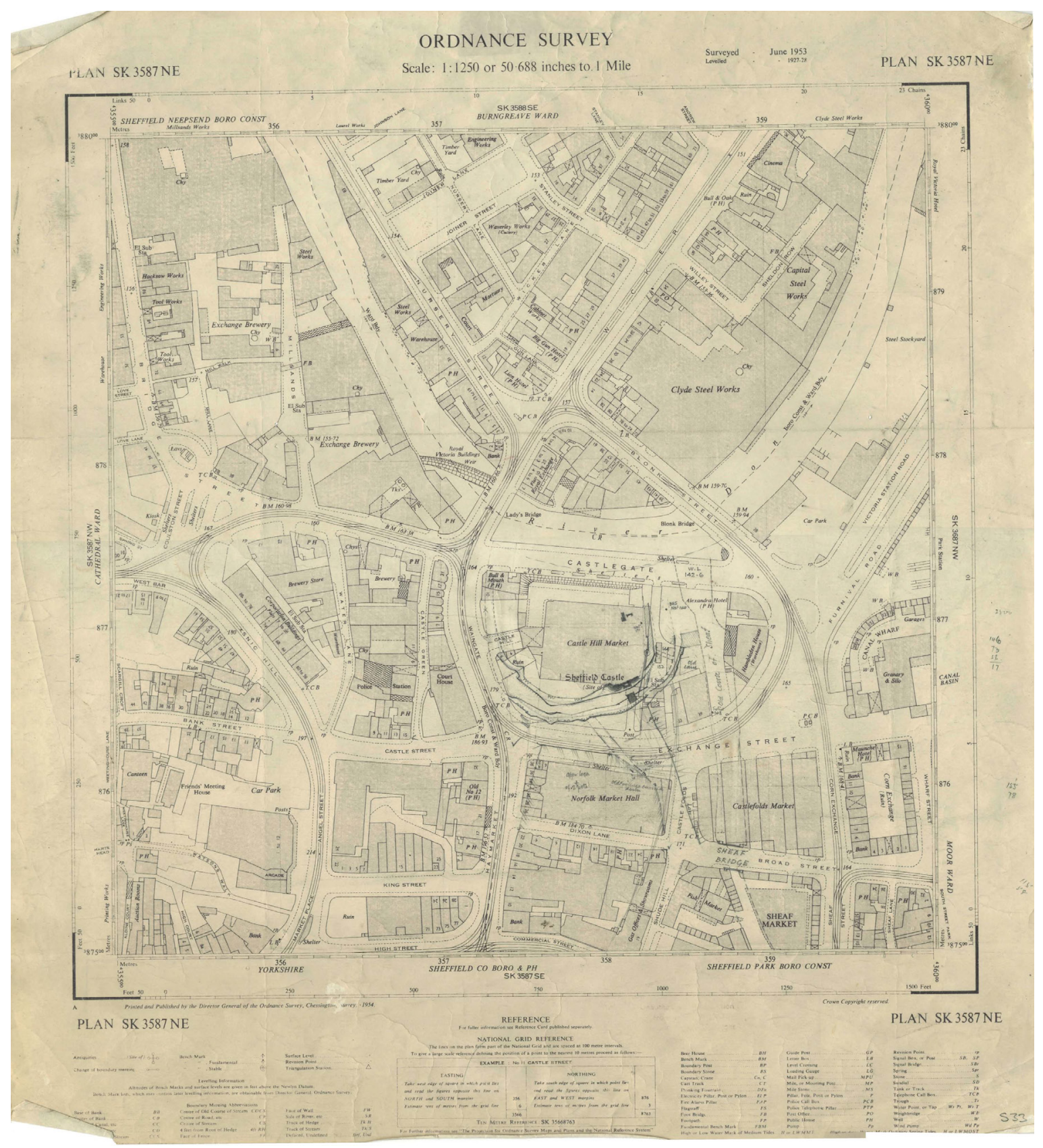

Figure 4.15: Ordnance Survey 1:250 map of Sheffield. Annotated by Leslie Butcher during his recording of the archaeological remains on Castle Hill. Courtesy of Museums Sheffield. 
Figure 5.23). Unusually in his drawing practice, his plans of the moat projected its course from the recorded positions of the moat cut and also showed both the width as excavated and the projected width allowing for the truncation of the site due to later construction work (Butcher n.d. (j)).

Another contrast with the work of Armstrong and Himsworth is that the artefactual record seems not to have influenced Butcher's thinking about the castle to any great extent, accentuating the impression that he may have been more interested in geology and geomorphology, and the formation processes operational on the site, than in the history of the people who lived there. His handwritten drafts and typescript make no reference at all to any of the artefacts he had recovered, and the typescript contains just a single comment about the AngloSaxon pottery Armstrong claims to have found, noting that he had been unable to locate any such pottery in the Armstrong archive (Butcher 1972a, 8). It is only in the short note for Medieval Archaeology in 1959 that Butcher refers to artefacts, and then only the pottery is explicitly mentioned, even though in the handwritten notes for that report there are other artefacts listed that he tellingly had deleted, including knives, a silver-inlaid spur, copper gilt pins, a minute die and a plaited rope of polytrichum commune, kitchen refuse, leather shoes and clay pipes (Butcher 1972b, 5). In another set of handwritten notes, as well as in the typescript (Butcher 1972a, 8), he wrote '[?dating material]', at the end of a section on the 'pre-1266' layers (Butcher 1972c, 9), suggesting that he intended to incorporate information from analysis of the finds, or at least recognised the importance of doing so. In a summary of planned future work outlined at the end of his 1961 lecture to the Hunter Archaeological Society (Butcher 1961, 4), he told his audience that 'All pottery - and small finds to be studied', and near the beginning of this typescript he (1972a, 3) commented that since the recording undertaken by Armstrong, 'Inevitably, too, new identifications and interpretations of portable artefacts have become necessary'. However, no such analysis was included in his text, even though in the 1960s there had been some attempts to catalogue at least the pottery from his excavations, as the museum archive contains a series of pottery drawings of this date ('Pottery illustrations', 1964-66); also from this period are likely to be a typed list of the boxes containing the artefacts, with information on which foundation shaft they were from ('Artefacts list', n.d.), and a collection of handwritten index cards containing descriptions of each sherd of pottery, including fabric and surface appearance by David Crossley (n.d.). Moreover, as we will see in Chapter 5, John Bartlett had acquired reports on environmental remains, but, again, Butcher made no use of these, and we have no evidence for other specialist reports. It is likely that the departure of Bartlett from Sheffield, followed by the Director, Singleton, who left to set up the Department of Museum Studies at the University of Leicester in 1966, weakened Butcher's links with the museum, just as he distanced himself from the Hunter Archaeological Society. Perhaps also Butcher simply left the finds analysis to the museum staff, regarding himself insufficiently expert to undertake this study (Nick Butcher pers. comm.) and changes in personnel saw the project fall by the wayside.

Whatever the case, we have one of the fundamental differences with the work carried out in the late 1920s, in which, as we saw in Chapter 2, what we might call 'finds specialists' played a role in extracting information from the materials recovered and fed it to Armstrong to allow him to tell the history of Sheffield Castle and its people. Tellingly, Butcher $(1961,8)$ told his Hunter Archaeological Society audience that the 'defects' in Armstrong's report on the 1920s excavations were perhaps 'merely those of another generation of archaeologists a generation preoccupied with objects qua objects'. It is difficult to avoid the conclusion that Butcher had a preference for those traces of the past that derive from, and inform us about, the longer-term processes of what has become known as 'deep history' (Gamble 2014; Shryock and Smail 2011), traces which, in their very nature, have less to tell us about people and the shorter-term, historical processes within which they operated. Indeed, although Butcher undertook research on the documentary evidence for the development of the castle, this does not feature in his draft typescript - his must be one of the only pieces on Sheffield Castle not to mention Mary, Queen of Scots! His focus is, however, recoverable from his handwritten notes on the medieval sources, which reveal that he seems to have been particularly interested in what the Civil War demolition accounts reveal about water management at that time (Butcher n.d. (a)). Again, it is processes rather than people that interested him. This preference for rooting explanation for change in natural forces might well derive from Butcher's geological background. However, it is notable that in British archaeology it coincides with the beginnings of the replacement of culture-historical perspectives (see Chapter 2) with ecological and economic approaches, exemplified by the work of Grahame Clark (Fagan 2001, 138-41), who had a run-in with Armstrong earlier in his career (Chapter 2, Section: Albert Leslie Armstrong: more than just the 'gifted amateur'). This privileging of the archaeological record over written sources was also in keeping with wider trends in the development of medieval archaeology in the mid-20th century. As Chris Gerrard $(2003,98)$ has argued, 
the range of excavations in British towns between the mid-1950s and 1970 'did much to break down the perception that historical documentation held all the answers'.

While Butcher did not live to publish the manuscript on which he was working in the early 1970s, he nonetheless played an important role in the dissemination of knowledge about the castle as some of the material he recovered went on display in Sheffield City Museum, following its aforementioned 1958-59 reorganisation. An enlarged version of his reconstruction drawing of the gatehouse was featured alongside a number of the items that he had found including four reconstructed pottery vessels, clay pipe fragments, an iron knife with bone handle, an iron spur with silver inlay, and a selection of pottery and iron finds from both his work and that of Armstrong (Museums Sub-Committee 1960, 12-13; Butcher 1958b; Figures 4.9, 5.18).

\section{Decoding the archive}

Although his typescript was seemingly close to being ready for publication, it cannot form the basis alone for an understanding of what Butcher recorded. It does not, for example, refer in detail to the findings from specific trenches and foundation shafts, and a good deal of the focus is on summarising the findings from the 1927-30 work. It also contains much less detail than can be found in the many handwritten drafts of the paper, which had clearly been trimmed out to prepare it for publication (e.g. Butcher 1972b; 1972c; 1972d; 1972e; 1972f). The typescript does not contain any illustrations, although it does list those he intended to incorporate, including numerous plans, elevations and isometrics, and photographs taken both during his own observations of the construction work and those of Armstrong (Butcher 1972a, 25-7), although it is not always easy to decipher specifically to which of the illustrations in the archive his list refers. Hence, one of the major tasks for our project was to integrate the findings summarised in this unpublished manuscript with the detailed information provided on the many plans, drawings and photographs in the archive, and the results of the first comprehensive analysis of the artefactual record (see Chapter 6). As we have seen, some of the areas investigated during the two periods of construction work recorded by Armstrong, Himsworth and Butcher overlapped, and this has allowed us to compare the findings. Key observations by Butcher relate to the east tower of the gatehouse, the make-up of the courtyard deposits, and the alignment and profile of the moat. Importantly, having analysed Harrison's 17th-century survey of the castle (see Chapter 1) and Ordnance Survey maps, he also highlighted the fact that the excavated area represented only the inner courtyard of the castle, and that a second courtyard, or outer bailey, lay to the south of Exchange Street (Butcher 1972a, 2).

In undertaking his work, Butcher utilised a recording system that was much more systematic than Armstrong's, with its heavy reliance on sketched (if measured) sections and plans, and notes in field diaries. It was based on the Ove Arup \& Partners (1957) engineering site plans, which show the locations of the service trenches, foundation shafts and manholes. As we have seen, the foundation shafts were arranged in a grid, and assigned a unique number/letter, which Butcher adopted in his recording. The grid was labelled from $\mathrm{A}$ at the south of the site to $\mathrm{K}$ at the north, and from 1 at the east to 24 at the west. There are several City Architect's Department plans in the archive that incorporate the original grid on which Butcher had made notes and sketches about the archaeology (Womersley and Butcher 1957a; 1957b; Figure 4.16). These annotated plans also show where shaft numbers have been altered, and where foundation shafts were combined into one during construction work. They are essential to our ability to locate the positions from which artefacts were retrieved, as these are generally marked with numbers that are derived from the grid. However, the location of a few of the foundation shafts cannot be precisely identified as they are assigned letter and number combinations not found on the grid.

The collection and recording protocol employed for the finds is represented on a flow diagram preserved in the archives bearing the names of both Bartlett and Butcher (n.d.), although it is uncertain who devised this (Figure 4.17). This shows the stages involved in recording the foundation shafts, in which three separate visits by the pair were envisaged, and indicates that the sections of the foundation shafts were to be labelled according to the depths that had been excavated. Artefacts would be identified by the letter 'P' and a number which would be recorded on the section drawings to identify the precise location (i.e. depth, face of the trench) from which they had been recovered. The finds would then be dated, and either boxed for further study, displayed or reconstructed. Unfortunately, however, analysis of the archive reveals that this system was not followed consistently, and on some section drawings the presence of artefacts is noted but these are not assigned a 


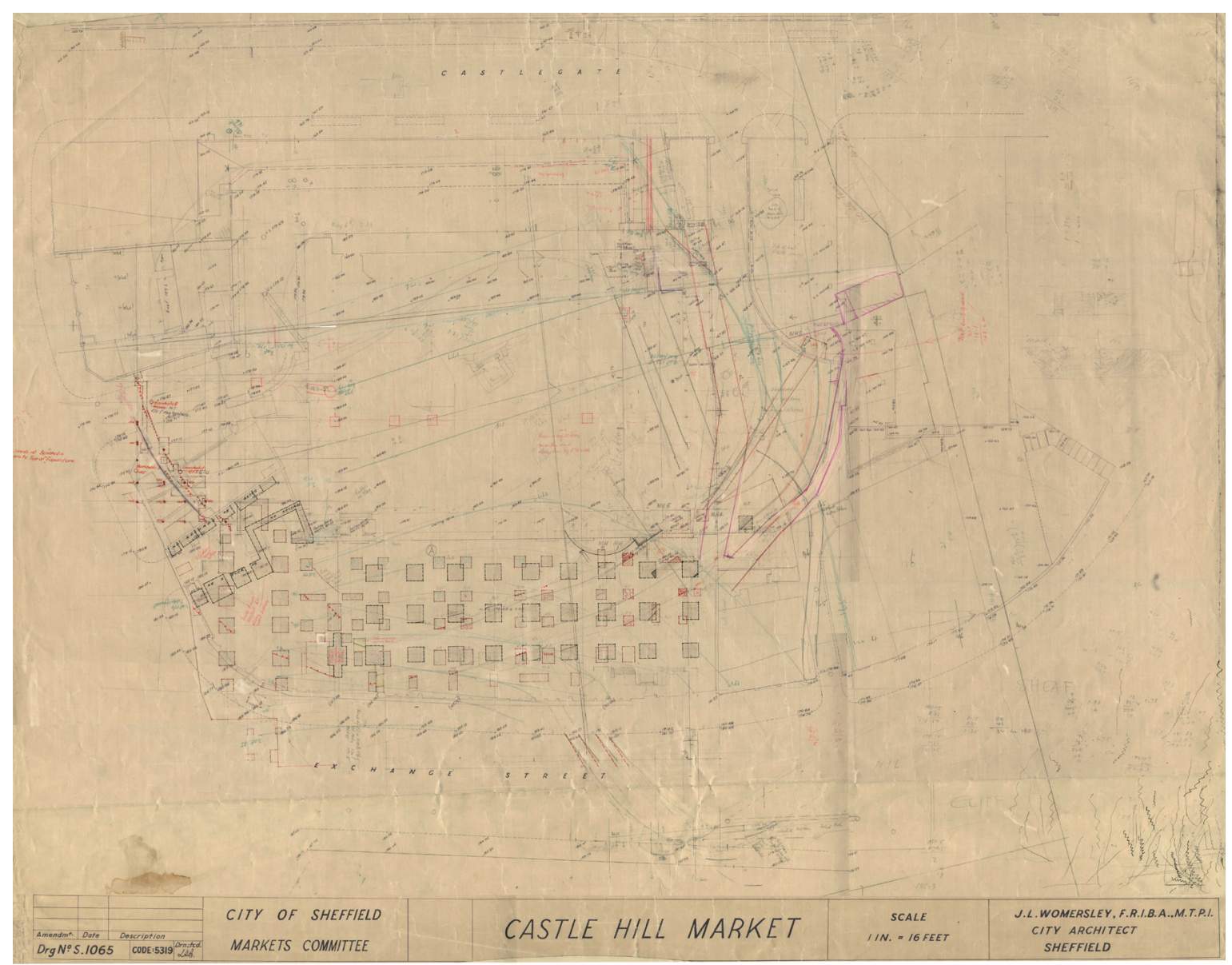

Figure 4.16: Plan of Castle Hill Market. Drawn up by City Architect J. Lewis Womersley and annotated by Leslie Butcher to show the locations of foundation shafts and boreholes. Courtesy of Museums Sheffield.

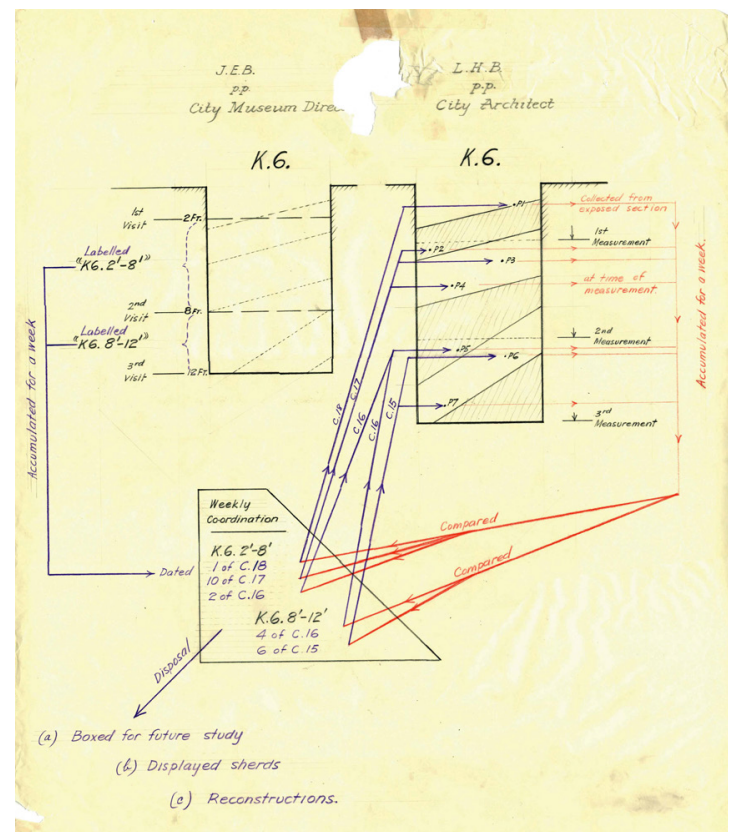

Figure 4.17: Finds processing flow diagram. This was created by John Bartlett and Leslie Butcher for their recording of the castle excavations. It is, however, apparent from our analysis of the archive that this model workflow was not consistently followed. Courtesy of Museums Sheffield. 
$\mathrm{P}$ number, or the letter $\mathrm{P}$ appears alone without a number, suggesting that the recording was incomplete. The methodology diagram suggests that $P$ numbers would run sequentially from the top of the foundation shaft on the first section drawing produced and that the numbering would continue through the other sections, but it is apparent from the most detailed section drawings that this was not carried through consistently and so it is not possible to guess at what depth and on which section any given P number might have been located if it does not appear on a section drawing. Even among the material recovered from the same foundation shaft, the extent to which P numbers and other context information are provided vary, and the references on the section drawings to finds are rarely sufficiently specific to identify individual objects (saying only, for example, 'bone', 'slag', etc). The result is that a significant proportion of the assemblage (up to $50 \%$ for some categories of object) must be regarded as essentially unstratified. We should also remember the circumstances of excavation on site and the limitations on recording. We know that the foundation shafts were hand dug - we can even see the individual pick marks on photographs of some of them - and that the kibbles were filled by hand, while Nick Butcher (pers. comm.) recalls the museum staff with Cyril and Pat James sifting through the previous day's kibble row, which must have been laid out on the ground (see the annotation to this effect on Butcher 1958-62d; Figure 5.14). So the idealised version of finds collection and reality did not fully accord.

Some of the items described on section drawings by Butcher could not be traced in the museum archive (e.g. leather annotated on the section drawings for foundation shafts G5, G7 and F21). While this is doubtless sometimes due to loss of context information in the archive, we also suspect that much, in particular the architectural fragments, was left in situ, although even some artefacts catalogued as recently as 2002 (Davies and Willmott 2002) have subsequently been misplaced. The assemblages from individual shafts vary greatly in size, and, while this may reflect meaningful differences in use or deposition of material culture across the site, other factors were also probably relevant to these differences. In particular, different recovery strategies must have been a factor, such as in the cases of foundation shafts F9, which produced just four sherds of pottery and no other finds, and F11, which produced five sherds of pottery and a medieval floor tile. Both of these shafts have some of the most limited recording on their section drawings, with those for F11 noting that it had been sheet piled and only the east section was drawn in detail (see Figures 5.29 and 5.30). There are also some finds from contexts for which we have no other information (e.g. foundation shaft E18), and there is uncertainty over the provenance of finds labelled as coming from ' $5 \mathrm{H}$ ', as this is not the standard format for identification of foundation shafts, which otherwise always have the letter first. This is probably a transcription error for H5, perhaps during rebagging/reboxing of the material in the early 1990s (Davies and Willmott 2002, 8; Dennison 2014, 3-5). Indeed, some of the finds are recorded as being from ' $5 \mathrm{HX}$ ' and ' $5 \mathrm{HY}$ ', which corresponds with information on the $\mathrm{H} 5$ section drawing, where Butcher uses a large ' $\mathrm{X}$ ' and ' $\mathrm{Y}$ ' to differentiate the lowest levels of the moat deposits close to the gatehouse, and the types of finds listed in the archive as being from $5 \mathrm{H}$ accord with those annotated on the $\mathrm{H} 5$ section drawing (Butcher 1958-62g).

The drawings contain many useful annotations about the nature of the deposits exposed, and the finds they contained, although some of the sections were not able to be recorded due to the use of shuttering, or have minimal information suggesting they simply could be completed in detail. The section drawings of foundation shafts produced by Butcher (1958-62a; 1958-62b; 1958-62d; 1958-62e) must often have necessitated him scaling long builders' ladders (Figure 5.2), and there is photographic evidence for him stringing up sections and measuring them amid the construction work (Figure 4.18). However, he may sometimes have drawn the foundation shafts off site on the basis of photographs; indeed, some of the photographs in the archive have been annotated with descriptions of layers that appear intended to inform his drawings (e.g. Butcher n.d. (s), no. 282; Figure 4.19). A handwritten legend for his plans and section drawings is contained within the archive showing the conventions he followed for drawing features, in which he distinguished what he had been able to record from 'probable' and conjectural features (Butcher 1972e). Details of the many photographs of the archaeology and construction work on the site, mostly taken by Cyril James, were annotated on an engineer's plan with the letters CA and a number written in red or green (e.g. CA12-1) or just a number written in purple associated with an arrow indicating the foundation pit to which they relate; the initials appear to relate to the person who took the photograph for which there is a key on the plan (e.g. 'LHB' for Butcher, 'CJ' for Cyril James, 'Newton' for Dr Ray Newton, whom Butcher thanked in one of his draft manuscripts; Ove Arup \& Partners and Butcher 1957). These numbers are replicated on the back of the photographs, as well as on a series of sheets onto which the photographs had been mounted and annotated by Butcher allowing them to be located precisely on the site plan (Figure 4.11). 


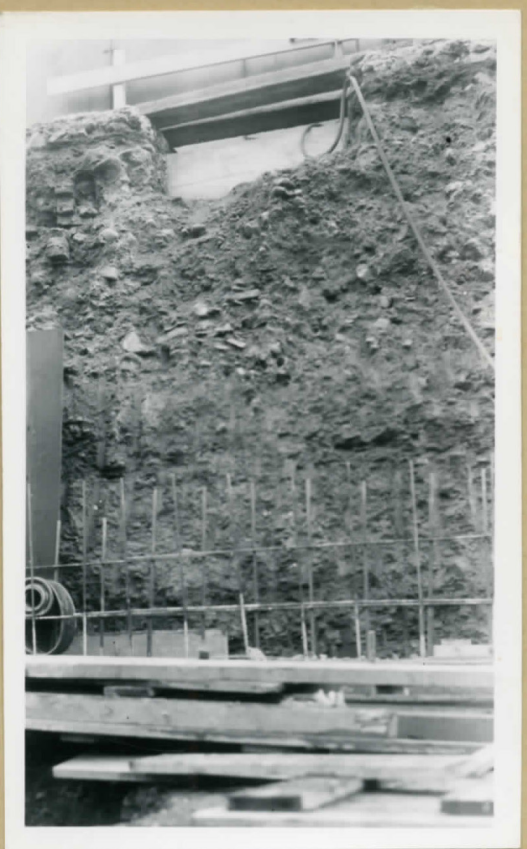

28

Exchange st

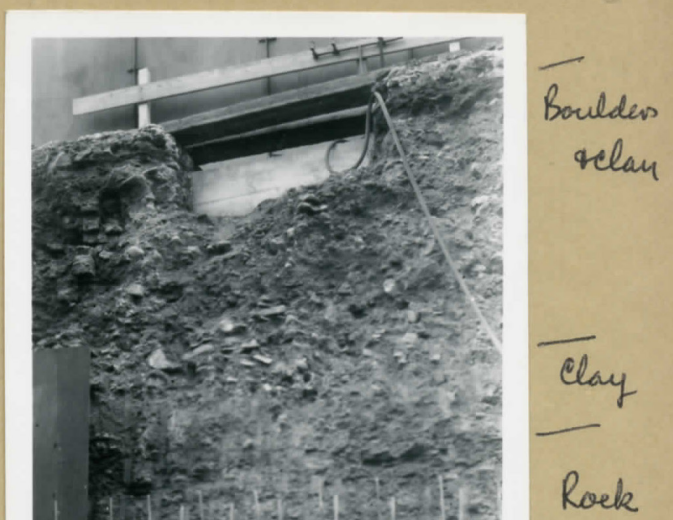

27

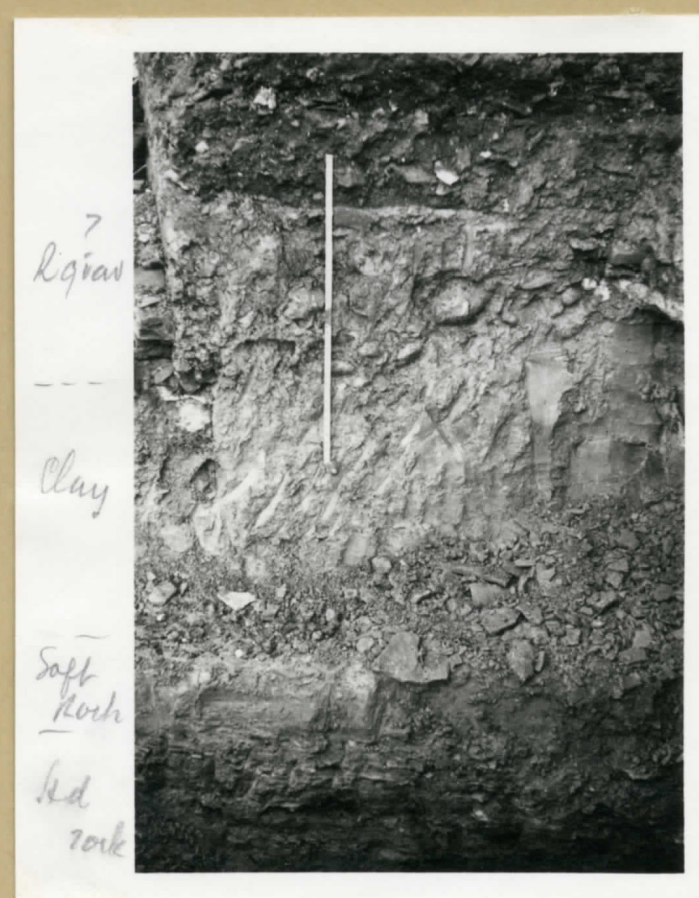

$$
\begin{aligned}
& \text { CA24 Ia21. } \\
& \text { Uaxinal quand below } \\
& \text { laler fire. }
\end{aligned}
$$

Figure 4.19: On-site photographs of exposed archaeology. These were subsequently annotated by Leslie Butcher, showing that, in these cases at least, he produced his drawings off site using photographs. The top two photographs also capture the building work amid which Butcher undertook his recording. Courtesy of Museums Sheffield. 


\section{Conclusion}

The circumstances in which Leslie Butcher and John Bartlett found themselves recording the archaeological remains of Sheffield Castle in the 1950s and 1960s were not radically different from those faced by Leslie Armstrong and Joseph Himsworth a generation earlier. Personal commitment to the heritage of the site, a recognition that 'something had to be done' and toleration if not active support from the local authorities were common to both eras, and given that little had changed in terms of archaeological procedure the opportunities presented for recording were similarly largely limited to a chequerboard view. The work undertaken on Sheffield Castle from 1958 was not located in a purely local context. As we have seen, Butcher had been closely involved in developing recording protocols through his work with Freddie Preston that responded to a growing national requirement to preserve information about heritage that was being lost to post-War development, and the galvanising force of Bartlett among the local archaeological fraternity had been a critical element in ensuring that endeavour succeeded. While Butcher may not have had the international profile of Armstrong, or his experience of a range of archaeological sites, in many respects his extensive understanding of geology and landscape made him extremely well equipped to record the moat and topography of the site, as we will see in the next chapter. Butcher was acutely aware of the importance of the work on the castle that he undertook, and with limited, if any, resources he, and a small group of volunteers, recorded what they could in difficult circumstances, and he worked doggedly over the following years to write it up. For him, however, it was not the famous inhabitants of the castle who were to be the focus; rather, it was the castle as a landscape feature and as a topographical conundrum to be resolved.

\section{Bibliography}

The full bibliography is available at the end of this volume, or at: https://doi.org/10.22599/SheffieldCastle.k. 